\title{
Location and agglomeration of FDI in The Netherlands: implications for policy
}

Citation for published version (APA):

Hogenbirk, A. E., \& Narula, R. (2004). Location and agglomeration of FDI in The Netherlands: implications for policy. MERIT, Maastricht Economic Research Institute on Innovation and Technology. MERITInfonomics Research Memorandum Series No. 006 https://doi.org/10.26481/umamer.2004006

Document status and date:

Published: 01/01/2004

DOI:

10.26481/umamer.2004006

Document Version:

Publisher's PDF, also known as Version of record

\section{Please check the document version of this publication:}

- A submitted manuscript is the version of the article upon submission and before peer-review. There can be important differences between the submitted version and the official published version of record.

People interested in the research are advised to contact the author for the final version of the publication, or visit the DOI to the publisher's website.

- The final author version and the galley proof are versions of the publication after peer review.

- The final published version features the final layout of the paper including the volume, issue and page numbers.

Link to publication

\footnotetext{
General rights rights.

- You may freely distribute the URL identifying the publication in the public portal. please follow below link for the End User Agreement:

www.umlib.nl/taverne-license

Take down policy

If you believe that this document breaches copyright please contact us at:

repository@maastrichtuniversity.nl

providing details and we will investigate your claim.
}

Copyright and moral rights for the publications made accessible in the public portal are retained by the authors and/or other copyright owners and it is a condition of accessing publications that users recognise and abide by the legal requirements associated with these

- Users may download and print one copy of any publication from the public portal for the purpose of private study or research.

- You may not further distribute the material or use it for any profit-making activity or commercial gain

If the publication is distributed under the terms of Article $25 \mathrm{fa}$ of the Dutch Copyright Act, indicated by the "Taverne" license above, 


\section{MERIT-Infonomics Research Memorandum series}

Location and agglomeration of FDI in The Netherlands: implications for policy.

Annelies Hogenbirk \& Rajneesh Narula

2004-006

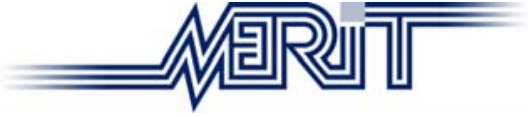

MERIT - Maastricht Economic Research Institute on Innovation and Technology

PO Box 616

6200 MD Maastricht

The Netherlands

T: +31433883875

F: +31433884905

http://www.merit.unimaas.nl

e-mail:secr-merit@merit.unimaas.nl

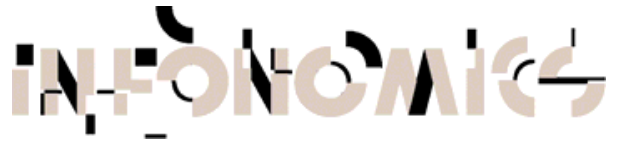

International Institute of Infonomics

c/o Maastricht University

PO Box 616

6200 MD Maastricht

The Netherlands

T: +31433883875

F: +31453884905

http://www.infonomics.nl

e-mail: secr@infonomics.nl 


\title{
LOCATION AND AGGLOMERATION OF FDI IN THE NETHERLANDS:
}

\author{
IMPLICATIONS FOR POLICY
}

\section{ANNELIES HOGENBIRK}

AND

\section{RAJNEESH NARULA*}

\begin{abstract}
Understanding the determinants of the location of MNE affiliates has become increasingly important for policy makers at the local, regional, national, and supra-national level, as investment promotion schemes are increasingly seen as an important cornerstone of the industrial development of most countries and regions. We examine some of the factors that explain an MNE's choice for a particular region within the Netherlands, and investigate whether agglomeration patterns can be detected, and how this establishment pattern relates to domestic firms. We also investigate if there are differences in locational choice prompted by the home country of the foreign investor. The results suggest that the determinants of location vary by home country and the nature of the affiliates, and also differs from the behaviour of domestic firms. We suggest that FDI promotion policies need to be aligned with industrial policy if governments are to benefit from the externalities that derive from MNE affiliates.
\end{abstract}

Keywords: foreign direct investment, the Netherlands, agglomeration, regions, multinationals, industrial policy, incentives, governments, EU

* Corresponding author: Dept. of International Economics and Management, Copenhagen

Business School, Howitzvej 60, 2000 Frederiksberg, Denmark. E-mail: $\underline{\text { nn.int@cbs.dk }}$ 
LOCATION AND AGgLOMERATION OF FDI IN THE NETHERLANDS: IMPLICATIONS FOR POLICY

\section{Introduction}

With the rapid increase in foreign direct investment (FDI) activity since the 1980s, there has been growing interest in the locational determinants of foreign establishments. FDI is increasingly regarded as an important potential contributor to the economic well-being of its location. Ceteris paribus, MNEs can be a significant source of technology, employment, and capital. Understanding the determinants of location of MNE affiliates has therefore become increasingly important for policy makers at the local, regional, national, and supra-national level, as investment promotion schemes are increasingly seen as an important cornerstone of the industrial policy of most countries and regions (Narula, 2003). Knowledge of the factors influencing a firm's location choice helps policy makers to design policies that enhance the attractiveness of a region for new investment (Carlton, 1983).

Most studies on locational choice investigate country-specific macro-economic factors such as market size, the presence of natural resources, infrastructure, and the skills-level and cost of labouri. Relatively few studies examine the determinants of the choice for a particular region in the selected host economy. Some of these studies concentrate on local establishments only (Carlton, 1983; Bartik, 1985) while others take both local and foreign or only foreign establishments into account (such as Head et al., 1995; Shaver, 1998; Woodward, 1992; Wu and Strange, 2000). Furthermore, many of the extant studies that analyse the regional determinants of location choice focus on relatively large countries such as the US and China where distinct regions exist that differ significantly in economic development and policies. 
The current study uses detailed establishment data for both local and foreign establishments in the Netherlands, examining the factors that influence how MNEs makes a choice for a particular region in a small open economy. Over 7000 foreign firms have establishments in the Netherlands. Here, we determine which factors explain their choice for a particular region within the Netherlands. We want to examine if agglomeration patterns can be detected in inward FDI in the Netherlands. Furthermore, we intend to investigate whether differences in regional location characteristics offer an explanation for the establishment pattern of foreign affiliates. Finally, we also investigate if there are differences in locational choice prompted by the home country of the foreign investor.

In Section two, we first discuss the different theoretical and empirical contributions to locational determinants of FDI and offer a conceptual model. Hypotheses based on this model are formulated in Section three. A description of the model used in the empirical analyses is given in Section four. The data are discussed in Section five, where we also analyse the overall establishment pattern of inward FDI in the Netherlands, considering the (dis-)-similarity in location choice of domestically-owned and foreign-owned establishments. In Section six, we discuss the results of the empirical model estimations. Policy implications and conclusions are given in Section seven.

\section{A brief overview of studies on locational choice}

With the increasing importance of multinational enterprises (MNEs), many theoretical perspectives have been developed to explain modes, motives, and locational choice for international business activities. We concentrate here on regional economic differences that might help explain the attractiveness of specific regional areas in a host economy. Several 
empirical studies examined the locational determinants of investments in particular regions (such as Bartik, 1985; Carlton, 1983; Cheng and Kwan, 2000; Friedman et al., 1992; Head et al. 1995; Kittiprapas and McCann, 1999; Shaver, 1998; Woodward, 1992; Wu and Strange, 2000). These studies tested hypotheses on a large number of variables that influenced the choice for a particular (host) location. Table 1 gives an overview of the most important results of these studies.

\section{*** Insert Table 1 about here ***}

Early studies on the determinants of a firm's location choice focused specifically on the choices made by local firms. Important examples include Carlton (1983) and Bartik (1985). Carlton (1983) estimates both the decision where to locate and how many employees to hire in three narrowly defined industries: fabricated plastic products, communication equipment, and electronic components in the US. Using simple logit models, he finds that in all these three industries energy costs have a positive and significant effect on the choice of location ${ }^{\mathrm{ii}}$. Both wage level and taxes (property and corporate) have no significant influence on location choice. Furthermore, Carlton (1983) finds strong evidence that existing concentrations of employment attract new establishments. Highly sophisticated industries (such as communication equipment) favour regions with available technical expertise.

Bartik (1985) uses a conditional logit model to analyse new branch plant location decisions for 1067 US manufacturing firms in the United States. The empirical results suggest that high unionisation has a very strong negative effect on new business activity in a state. Investments are deterred when firms expect difficulties in hiring and firing employees. Furthermore, locations with low corporate taxes appear attractive for new manufacturing plants ${ }^{\mathrm{iii}}$. Large states attract 
more investments than smaller ones (because more interesting sites are available) and existing manufacturing activity makes a region more attractive for new establishments. Wage rate, population density, energy prices, and road infrastructure have no significant effect on the choice for a particular location in the US.

Following these early location studies, several scholars have extended these analyses by taking the country of origin of the investments into consideration (Friedman et al., 1992; Head et al., 1995; Shaver, 1998; Woodward, 1992; Wu and Strange, 2000). Shaver (1998) analyses whether foreign-owned and US-owned establishments exhibit the same location patterns in US manufacturing industries in 1987. The 50 US states clearly vary in attractiveness for foreign and local firms and these differences cannot be attributed to the fact that foreign firms are relative latecomers in the US. Shaver (1998) finds that compared to US firms, foreign affiliates favour coastal areas more strongly ${ }^{\mathrm{iv}}$. Foreign firms also favour states with low unionisation rates and higher unemployment more than US firms. Several variables - the level of economic activity, corporate taxes and per capita income - do not exhibit statistically significant coefficient estimates. Shaver (1998) therefore concludes that both foreign and local firms are equally attracted by these factors.

Friedman et al. (1992) use conditional logit modelling to analyse the location decisions of 884 new foreign multinational manufacturing enterprises in the United States. They separately study the site selections (between 1977 and 1988) of all foreign MNEs, Japanese MNEs, and European MNEs. Their results indicate that at the level of the individual state the following factors offer significant explanations for the choice for a particular US state: access to markets, labour market conditions ${ }^{\mathrm{v}}$, state promotional efforts, transportation infrastructure, and taxes. The decision determinants are found to differ between Japanese and European firms. The former put much 
more emphasis on labour conditions, corporate taxes, and the number of potential sites (measured by total land area) than the latter.

Woodward (1992) uses a conditional logit model to analyse 540 Japanese-affiliated manufacturing investments in the United States for the period 1980-1989 ${ }^{\mathrm{vi}}$. He finds evidence that Japanese investors favour states with strong markets and low unionisation rates and dislike states with high taxes. Regional support from Japanese investment agencies located in the US also facilitates new establishments in US states. Furthermore, Japanese firms generally select counties characterised by manufacturing agglomeration, low unemployment and poverty rates, and concentrations of educated, productive workers. In rural areas, interstate highway connections positively influence the location of new Japanese investments while population density (signalling urbanisation) has no significant effect.

Head et al. (1995) examine the location choices of 751 new Japanese manufacturing plants in 225 four-digit manufacturing industries built in the United States since 1980. Instead of looking at the individual regional characteristics, they consider agglomeration variables and employ state-specific constants to capture unobserved variation between states. They find that Japanese establishments do not simply mimic the geographical pattern of US establishments. Head et al. (1995)'s estimates support the hypothesis that industry level agglomeration benefits play an important role in location decisions. Japanese's firms favour regions where there are already relatively many US establishments in the same industry. Furthermore, they choose locations that were also chosen by previous Japanese investors, either in the same industry, or from the same keiretsu.

Cheng and Kwan (2000) estimate the effects of the determinants of foreign direct investment (FDI) in 29 Chinese regions (including export-processing zones specifically targeted to receive FDI) from 1985 to $1995^{\mathrm{vii}}$. They find that a large regional market, good infrastructure, and 
preferential policy had a positive, but regional wage costs had a negative effect on FDI. In addition, there was a self-reinforcing effect of FDI on itself, consistent with agglomeration effects. Education levels had no significant effect on the attractiveness of a region in China. Wu and Strange (2000) analyse the location choice of 138 foreign insurance companies from 11 home countries that opened representative offices in six cities in China during the period 19921996. They use conditional logit modelling in their analyses and find that proximity to the headquarters of the government's Regulatory Authority - that grants operating licenses for both life and non-life insurance - (measured as proximity to government institutes) is an important determinant explaining the establishment pattern of those foreign insurance companies. Furthermore, market size and the presence of other foreign investors are found to have significant positive effects upon the choice of location. Wu and Strange (2000) therefore find strong support for the assumption that foreign service firms are inclined to locate near agglomerations of (foreign) producers because such agglomerations provide proximity to competitors, to suppliers, to clients, and to a pool of skilled labour. Foreign insurance firms favour regions in China that are open to the award of operating licenses. Most regions are currently still closed for foreign investment and therefore unattractive as locations. Labour related variables are found to be of little significance.

Most studies look at the (economic) characteristics of regions within the host country but ignore the specific characteristics or purposes of the investing firm. One important exception is the study conducted by Kittiprapas and McCann (1999). Instead of looking only at the characteristics of the regions, they incorporate characteristics of the individual firm (such as size) as well. They analyse the establishment pattern of 156 electronics firms in 4 regions in Thailand. Using binomial logit to clarify the choice for Bangkok compared to the rest of Thailand, they find that both regional wage levels and Thai ownership positively influence the choice for Bangkok. Their 
findings suggest that the existence of localised agglomeration economies positively influence the attractiveness of regions.

Our understanding of this body of the literature suggests that the variables influencing the choice for a particular location within a host country (presented in Table 1) can broadly be classified in six groups: 1) agglomeration variables, 2) market variables, 3) labour variables, 4) government policy, 5) infrastructure, and 6) geographic variables. This classification results in the conceptual model of the determinants of regional location choice presented in Figure 1.

*** Insert Figure 1 about here ***

\section{Hypotheses}

As shown in Table 1 and Figure 1, the variables influencing the regional location choice in a host economy can broadly be organised in six groups: agglomeration variables, market variables, labour variables, government policy, infrastructure, and geography. This section formulates hypotheses that apply to the Dutch situation for each of these groups of variables as specified in our conceptual model. The main potential determinants of foreign investors' regional location choice in the Netherlands are:

1. Agglomeration variables: Theoretical analysis has developed various explanations for manufacturing agglomeration. The early work of Marshall (1920) provides three reasons for spatial concentration in industries: (a) localisation provides a pooled market for workers with special skills, (b) facilitates the development of specialised inputs and (capital) services, and (c) 
enables firms to benefit from technological and knowledge spillovers. New contributions have built on Marshall's ideas, emphasizing increasing returns to scale, transportation costs and knowledge spillovers (Caniels and Romijn, 2003; Krugman, 1991; Pinch et al., 2003).

Several studies have investigated the importance of agglomeration as a determinant of location choice. A common finding in many recent location studies is that regions with relatively many foreign establishments are more likely to attract additional investments than locations that have only a few foreign firms present. Wheeler and Mody (1992) ${ }^{\text {viii }}$ have investigated the importance of agglomeration economies on the foreign investment decision of US firms in manufacturing and electronics for a panel of 42 countries for the period 1982-1988. They find that the presence of many other foreign firms in a region (which can be seen as an indicator of agglomeration) matters significantly as a determinant of new FDI inflows. Furthermore, Braunerhjelm and Svensson (1996), who studied the establishment pattern of Swedish MNE affiliates abroad, find evidence supporting the importance of agglomeration effects, particularly for Swedish high-tech firms operating in the OECD countries. These firms tend to locate manufacturing affiliates in geographically well-defined areas specialised in similar production ${ }^{\mathrm{ix}}$. Barrell and Pain (1999) emphasise the importance of agglomeration effects in the location pattern of US affiliates in the European Union (EU). They pay particular attention to the effects of the process of EUintegration and the resulting increased attractiveness of the EU. They find that both centrifugal forces (pushing out foreign firms, such as high costs) and centripetal forces (attracting additional FDI, such as agglomerations of other foreign firms) matter for location decisions by US firms in the EU. Head et al. (1995) find strong evidence supporting the positive effect of foreign agglomeration on location choice by 751 new Japanese plants built in the US since 1980. Given the overall positive influence of agglomeration, we expect that other foreign establishments will 
encourage new FDI into a region due to knowledge spillovers and supplier linkages. Thus our hypothesis regarding foreign agglomeration is as follows:

H1: The presence of foreign establishments in a region positively influences new foreign investment in that region.

Agglomeration may also occur around local firms. The expected effect of the presence of local firms can be either negative or positive. Like foreign establishments, a large number of local establishments could positively influence the attractiveness of the region due to knowledge spillovers and a large pool of skilled labour in the region. Bartik (1985), for instance, shows that the presence of existing manufacturing activities in a region attracts additional investments. Furthermore, Head et al. (1995) find that Japanese affiliates are attracted to regions in the US where many local US firms are located.

On the other hand, the presence of many local competitors may also be a deterrent to new investments due to the presence of local competitors and the expected rivalry. Furthermore, the pool of skilled labour might be too small for the number of firms present in the region, resulting in fierce competition for labourers and therefore in high costs. This point of view has not been tested before. Considering that foreign firms suffer from the liability of foreignness and are less familiar with Dutch business rules and customer taste, the presence of many local competitors with better market knowledge may deter the entrance of foreign affiliates in a region. We therefore propose the following two competing hypotheses regarding local agglomeration:

H2a: The presence of local establishments in a region positively influences new foreign investment in that region. 
$H 2 b$ : The presence of local establishments in a region negatively influences new foreign investment in that region.

2. Market variables: Many firms invest in a particular country or region to supply goods or services in these or adjacent countries. These market-seeking investments are undertaken to sustain or protect existing markets, or to exploit or promote new markets (Dunning, 1993). Several studies therefore emphasise the importance of the market size in attracting additional investments to a region. Woodward (1992) models the locational determinants of 540 Japanese manufacturing start-ups in the United States (US). He finds that Japanese investors favour states with strong markets and low unionisation rates while they avoid less-developed areas with few educated workers, high unemployment and high state unitary taxes. Areas that are characterised by high GDP per capita are considered to have high (potential) demand for goods and services. High demand also results in possible economies of scale and therefore makes an area more attractive for investors. Following Woodward (1992) we therefore expect that a larger regional market will attract more new foreign establishments and hypothesise:

H3: A larger market size in a region positively influences new foreign investment in that region.

3. Labour variables: Apart from market-seeking investments, foreign establishments can be motivated by resource-seeking arguments. Investments can be prompted by the need to acquire technological capability, management or marketing expertise, and organisational skills (Dunning, 1993). Labour is an important income-generating asset for the firm and labour market conditions therefore are an important determinant of the attractiveness of a region. Several studies have 
proxied the available workforce by population density (see for instance Bartik, 1985 and Woodward, 1992, Table 1). We expect this variable to have a positive effect on the decision to locate in a particular region.

H4: A higher population density in a region positively influences new foreign investments in that region.

Labour market conditions are also reflected in the level of unemployment in the region ${ }^{\mathrm{xi}}$. The effect of unemployment on the location decision of foreign firms is not easily decided beforehand. Following Carlton (1983) unemployment is considered for the following reasons. On the one hand, high unemployment can signal low local demand. Even though most establishments will target national markets, local spurts in demand (with which the unemployment variable is negatively correlated) could raise prices locally and thereby stimulate locational activity. Furthermore, high unemployment can signal a lack of suitable employees making a region unattractive for foreign firms. On the other hand, it is also possible that especially for larger firms, an area with a high unemployment rate might be attractive. A high unemployment rate can reduce the initial and subsequent costs of assembling and maintaining a workforce. High unemployment can then serve as a proxy for the available workforce (Woodward, 1992). This argument is partially confirmed by Shaver (1998). Having no theoretical argument to prefer one argument over the other, we suggest two opposing hypotheses:

H5a: Higher unemployment in a region negatively influences new foreign investment in that region. 
H5b: Higher unemployment in a region positively influences new foreign investment in that region.

4. Government policy: Most studies on FDI location take taxation differences into account (Bartik, 1985; Woodward, 1992; Shaver, 1998). High taxes increase the costs of doing business in a particular location (partly also by the administrative burden) and therefore reduce profitability. This is particularly relevant for studies in the US, where taxation levels differ significantly among states. However, this is not the case in the Netherlands. Tax levels are equal all over the country. The only tax-rate that differs is the real estate property tax, decided upon by individual cities. We expect that high property taxes will negatively influence the decision to locate in a particular region due to an increase in costs of doing business. We therefore hypothesise:

H6: $\quad$ Higher real estate property taxes in a region negatively influence new foreign investment in that region.

5. Infrastructural variables: The choice for a particular region is influenced by the transport and communication costs incurred in that area. The infrastructural provisions therefore influence the attractiveness of a region for new investments (Dunning, 1993). If an area is characterised by well-developed utilities and an extensive knowledge- and transportation infrastructure, this reduces the costs and increases the reliability of transportation and therefore makes the area more attractive for FDI (Cheng and Kwan, 2000). This is particularly important if the goods produced at the location are targeting the export markets, which can be expected in a small economy. Particularly in case of the Netherlands, we expect many foreign firms to use the Netherlands as 
an export-hub for the rest of the European Union. Ease of transportation is then an important factor that determines the choice for a location in the Netherlands. Following Bartik (1985) we include roads per area as an indicator of the sophistication of the infrastructure in a region. We expect this variable to have a positive influence on the decision to locate an affiliate in a region. Better infrastructure $^{\mathrm{xii}}$ results in better accessibility of a region and easier access to other region (or countries) which facilitates the distribution of both inputs and outputs. Thus our hypothesis regarding the quality of infrastructure is as follows:

H7: Large infrastructural provisions in a region positively influence new foreign investment in that region.

It would have been interesting to consider other infrastructural measures such as knowledge infrastructure etc. particularly since those are important in the services sector that attracts a lot of FDI in the Netherlands. However, statistics on these variables are currently not available on a regional level.

6. Geographic variables: The geographical size of a region can affect the number of sites available to decision-makers. The larger the area, the more sites potentially available to an investor and therefore the more attractive the area is for foreign investment. We therefore expect land area to have a positive effect on the probability of a region being chosen (Bartik, 1985; Friedman et al., 1992; Woodward, 1992), resulting in the following hypothesis:

H8: A large available area in a region positively influences new foreign investment in that region. 
A number of studies have found a preference of foreign investors to locate in a region close to their home country (Head et al., 1995). This can result in a cost advantage in case intermediary inputs have to be transported to the affiliate (Shaver, 1998). Furthermore, we can expect a cultural similarity in bordering regions that facilitates doing business there. We therefore expect firms from Japan and the US to favour other Dutch regions than European establishments. Particularly German and Belgian firms are expected to favour regions neighbouring their countries (such as Noord Brabant, Limburg, Gelderland, see Figure 2). We thus suggest the following hypothesis:

H9: $\quad$ Multinationals from countries that have a border with the Netherlands are more inclined to invest in regions that are attached to their home country than firms from countries that are not direct neighbours.

Figure 3 summarises the hypotheses presented in this section.

*** Insert Figure 3 about here ***

\section{The Model}

We model the location decision of foreign firms in the Netherlands as a conditional logit problem where the dependent variable is the area in the Netherlands chosen by each investor ${ }^{\text {xiii }}$. We follow the method successfully employed in earlier studies such as Carlton (1983), Bartik (1985), Woodward (1992), Head et al. (1995), and Shaver (1998). The models are based on 
McFadden's model $(1974,1978)$. All studies investigate the odds of locating in a particular region and assume that each investor will make the location choice for its affiliate on the basis of trying to maximise the expected future profits from its investment. These future profits depend upon a number of attributes of each potential region. These attributes all have an effect on future revenues and costs. Therefore, the decision for a specific location takes into account the attributes of the chosen location relative to the other alternative locations. A foreign firm will choose the Dutch region that yields the highest profit.

Following our conceptual model presented in Figure 3, regional location choice can be considered a function of six sets of variables: (1) agglomeration effects (A); (2) market variables (M); (3) labour variables (L); (4) government policy as measured by taxes (T); (5) infrastructure (I); and (6) geographic variables (G). We can therefore consider the location choice of foreign establishments $\left(\mathrm{L}_{\mathrm{f}}\right)$ as:

$$
\mathrm{L}_{\mathrm{f}}=\mathrm{g}(\mathrm{A}, \mathrm{M}, \mathrm{L}, \mathrm{T}, \mathrm{I}, \mathrm{G})
$$

The profits of a new establishment $\mathrm{t}$ at location $\mathrm{j}\left(\pi_{\mathrm{j} t}\right)$ are a function of a vector of observed characteristics $\mathrm{Xj}$ of the site $\mathrm{j}$ (where $\mathrm{X}=\{\mathrm{A}, \mathrm{M}, \mathrm{L}, \mathrm{T}, \mathrm{I}, \mathrm{G}\}$ ) plus a disturbance term $\varepsilon_{\mathrm{jt}}{ }^{\mathrm{xiv}}$ or

$$
\pi_{j t}=\beta^{\prime} X_{j}+\varepsilon_{j t}, \quad \quad \mathrm{j}=1, \ldots, \mathrm{J}
$$

Location $\mathrm{j}$ is one of the 12 provinces in the Netherlands ${ }^{\mathrm{xv}} . \beta$ is a vector of parameters to be estimated. Following McFadden (1974, 1978), we assume that the disturbance terms are independent and identically distributed (iid) according to the Weibull distribution. Under this 
assumption the probability of locating an establishment $t$ at location $\mathrm{j}$ is given by the logit expression:

$$
\operatorname{Pr}[\text { region } \mathrm{j}]=\frac{e^{\beta^{\prime} X_{j t}}}{\sum e^{\beta^{\prime} X_{j t}}}
$$

Estimations of $\beta$ may be obtained with maximum likelihood estimation ${ }^{\mathrm{xvi}}$.

\section{The data}

Two types of data are used for this study. The first dataset contains information on new foreign establishments in the Netherlands. The establishment data are taken from the DutchInvest database (for a full description of the database see the appendix). We consider both a five-year period running from 1992 to 1996 and a subset of this data set covering the years 1995-1996. Our study comprises 1435 (357) new foreign establishments from 40 (24) home countries. An overview of the countries and the numbers of new foreign affiliates from those countries is given in Table 2 for both time periods. A map of the Netherlands showing the foreign establishments is given in Figure 2.

*** insert Figure 2 about here ***

Based on the DutchInvest-data we have tested whether the locational choice of foreign establishments in the Netherlands matches that of local Dutch firms, employing a $\chi^{2}$ test on a $2 \mathrm{x}$ 
12 table, where the columns represent foreign-owned and Dutch establishment counts, and the rows each present a region in the Netherlands. Table 3 presents the establishment counts $^{\mathrm{xvii}}$ of foreign firms operating in the Netherlands. The test statistic $\left(\chi_{11}^{2}=2158\right)$ rejects the nullhypothesis that the location distributions for Dutch-owned and foreign-owned establishments are identical at the 0,0001 level. Foreign and Dutch firms clearly differ in their location choice, even though they seem quite similar at first glance. Foreign firms favour the Randstad, while they have very little interest in opening plants or offices in the other provinces.

\section{*** Insert Table 3 about here ***}

It is therefore very interesting from a policy point of view to determine which factors influence the foreign firm's choice for a particular location in the Netherlands. We distinguish two levels of analysis. First of all, the Randstad-area (broadly encompassing the provinces Noord Holland, Zuid Holland and Utrecht, see Figure 2) versus the rest of the Netherlands. The Randstad benefits from its favourable location near the North Sea and good infrastructural provisions such as Schiphol airport and the Rotterdam harbours. Furthermore, large cities such as Amsterdam, Rotterdam, The Hague, and Utrecht are important business centres in this region. We therefore expect foreign firms to choose between the Randstad and the rest of the Netherlands.

The second level of analysis is provincial. We look more closely at the attractiveness of each of the twelve individual provinces of the Netherlands. Although they are basically administrative entities, some distinctly stand out due to their own language (such as Friesland) or history (the newly developed land in Flevoland). We would like to determine whether characteristics of the provinces can explain their attractiveness to foreign affiliates. Considerable effort was spent to make the dataset as accurate as possible. Table 4 lists all the independent variables used in this 
model, their definition and source, and the expected signs of their influence on the choice of a region for the establishment of an affiliate (see also Figure 3). For all independent variables we considered the situation at the beginning of the period studied for the five year (two year) sample: January 1992 (1995). We use a small subset of the data to reduce the potential variation in relative infrastructure levels and factor prices that could also influence a location's attractiveness. Most variables are considered as logarithms, with the exception of unemployment, which is already a percentage.

\footnotetext{
*** Insert Table 4 about here $* * *$
}

We added two groups of control variables to the model: country and sector dummy variables. Regarding the home country of the investor, we introduced a dummy variable for the European Union (EU) countries. Given that the Netherlands is part of the EU we wanted to control for the effects of EU integration in the analyses. Furthermore, we also separated the US investors from the total sample, considering that the US is the largest single home country of investments in the Netherlands. Japanese investments are unique because they only started in the 1980s. We therefore also controlled for their presence by introducing a Japan dummy in the analyses.

We also control for the different sectors in the sample by introducing dummy variables for manufacturing firms and holding companies. We expect that manufacturing firms need more space and will therefore favour locations outside the overcrowded Randstad-area where transportation is hindered by traffic jams. Holding firms ${ }^{\text {xviii }}$ have an exceptional position in the Netherlands (DNB, 2000a). Most of them concentrate on financing and facilitating the multinational's activities. Given the nature of their activities, we expect them to favour the Randstad-area. 


\section{Results and discussion}

The results are presented in Table 5. Specifications 1-4 present choice between Randstad and the rest of the Netherlands, specifications 5-8 the choice for one of the 12 Dutch regions. Since we have taken the logarithms of the independent variables, the results of all variables have interpretations as being proportional to the change in the probability of foreign investment in a region that results from a 1 percent change in the independent variable. Therefore a direct comparison between coefficient magnitudes of different variables can reveal which factors exert the most influence on location selection by foreign firms in the Netherlands.

Overall, the results are quite promising though limited due to multicollinearity among the variables describing regional characteristics ${ }^{\mathrm{xix}}$. We are therefore unable to test all related variables at the same time. The results presented have the maximum number of variables included. The results from specifications 1-8 are generally consistent with the expectations in the hypotheses and show the expected signs of relationship between location choice and determining factors. However, particularly for the regional characteristics, only a few variables actually are significant.

\footnotetext{
*** Insert Table 5 about here ***
}

Table 6 gives an overview of the hypotheses and the test results. We separately look at the results of the analyses for the Randstad-area (specifications 1-4) and for the 12 provinces (5-8).

\footnotetext{
*** Insert Table 6 about here $* * *$
} 
Regarding the agglomeration variables, the overall results offer strong support for hypothesis 1 . Foreign firms tend to follow their predecessors, trusting their choice and hoping for positive spillovers from clustering such as a pool of specialised labour and input and technical and knowledge spillovers. This result confirms earlier studies by Head et al. (1995), Pinch et al. (2003), and Wu and Strange (2000).

We find that the presence of many local firms turns out to be a significant deterrent for new foreign establishments in the Randstad in most specifications, in line with hypothesis 2b. This result contradicts earlier studies by Bartik (1985), Head et al. (1995) and Woodward (1992) that all emphasise the positive influence of agglomeration of manufacturing activity and overall production in a geographic area. However, particularly in the Randstad, where almost half of all Dutch firms are located, foreign firms may be discouraged by the threat of intense rivalry by local firms in the region. Because internationalisation is inherently risky, ceteris paribus, initial foreign investments tend to be small in size and are therefore not capable of exploiting economies of scale and scope. Furthermore, those new foreign firms are unfamiliar with local customs and regulations and therefore have more difficulty conducting business. Areas that are characterised by heavy competition may therefore not be the most attractive locations for new foreign establishments.

Regarding the market variable (market size) specifications 2, 6, and 8 appear to confirm the expectation that a larger market attracts more foreign investors (hypothesis 3), although only in the case of specification 2 is this result significant at the 1 percent level. However, in specification 4 we find significant proof of the opposite effect. The effect is therefore inconclusive. 
The effect of the labour variables is small and insignificant in most specifications. Due to multicollinearity problems, population density could only be tested in the conditional logit model for the small sample (1995-1996). Although the parameter is correctly signed, confirming our expectation that a high population density increases the likelihood of foreign investment, the effect is not significant. We therefore cannot confirm hypothesis four based on our results. The influence of unemployment is positive for both specifications (and significant for specification 2) regarding the choice between the Randstad and the rest of the Netherlands. We therefore find some support for hypothesis 5b. A high unemployment rate signals a pool of available labour and therefore reduces the initial and subsequent costs involved in the assembly and maintenance of a useful labour force. This result is in line with studies by Friedman et al. (1992) and Shaver (1998).

The influence of government policy is proxied by the property taxes variable. Its effect is small and insignificant, therefore rejecting hypothesis six. This result is contrary to evidence regarding taxes in studies such as Friedman et al. (1992) and Woodward (1992). However, this is not very surprising given the relatively small regional variations in this variable in the Netherlands. In addition, property taxes are only a very small percentage of the total tax burden faced by foreign and local firms. Corporate taxes are much more important but their level is determined for the entire country in the case of the Netherlands.

The infrastructure in the area, measured by the road density, exerts a positive but insignificant influence of foreign establishments in estimations 2,6 , and 8 . However, when testing the same variables listed in specification 2 for the large sample (not shown in Table 5), infrastructure does exert a large, positive and significant influence on the choice for the Randstad area ${ }^{\mathrm{xx}}$. Hypothesis seven is therefore confirmed for the Randstad. 
Land area has a significant negative influence in specification 6. This finding contradicts our expectations in hypothesis 8. Despite the small size of the Randstad-area, most foreign firms still want to be there, signalling that other factors compensate for the lack of space. We expect the densily-populated Randstad to be particularly attractive for knowledge-intensive industries and services that need relatively little space. Other factors - such as available labour and infrastructure - will compensate for the disadvantage.

Hypothesis nine explored the relationship between home country and location choice. From the results for the larger sample it is clear that relative to European and other firms, Japanese and US firms favour the Randstad more. When testing the variables of specification 2 for the large sample (not shown in Table 5), we find a strong and significant negative influence of EU on the choice for the Randstad $^{\mathrm{xxi}}$. This relationship is further explored in Table 7 where we take a closer look at the establishment patterns of German, Belgian, UK, US, Japanese, and all European establishments. We expect Japanese and US firms to value the transportation facilities in the Randstad area more, given their distance from the Netherlands. On the other hand, affiliates whose parents are in neighbouring countries may be more inclined to choose the border-regions that are closest to their home. We test our expectations with $\chi^{2}$ tests.

\footnotetext{
*** Insert Table 7 about here ***
}

From Table 7 it is clear that establishment patterns differ significantly per home country. Hypothesis nine is confirmed by the data. Firms that have a parent in Belgium and Germany favour border regions over the rest of the Netherlands. Important explanations include low transportation costs, familiarity with the area, knowledge of the Randstad-problems (such as traffic congestion), and cultural similarity will encourage these establishments. Japanese and US 
firms favour Randstad locations. This result seems to suggest that firms from more distant foreign countries have a more "simplistic" location choice pattern. They favour the most obvious location: the Randstad, where the capital of the Netherlands (The Hague), three more large cities (Amsterdam, Rotterdam, and Utrecht), and large infrastructural facilities (Schiphol, Rotterdam harbours) are located.

For the Randstad or rest of the Netherlands specifications (2 and 6) we also tested the importance of the kind of activity conducted by the foreign affiliate on its location choice. We find strong and significant evidence that, relative to all other establishments, the holding companies tend to favour the Randstad area. This result confirms earlier observations by Boeckhout et al. (1987). This choice can be explained by the need for holding offices to be close to good infrastructural facilities (including banks, office space, and telecommunications) that is readily available in the Randstad.

\section{Policy implications and conclusions}

This paper has examined some of the determinants of foreign affiliates' location preferences amongst regions within the Netherlands. Despite certain limitations that arise from multicollinearity problems, our results suggest important policy implications at the regional, national, and supra-national level. These different levels of analysis are not mutually exclusive: regions within countries, countries within the EU, and indeed the EU as a single political and economic entity compete with other regions and countries for FDI. As new countries join the EU, each seeking to enhance their locational attractiveness to MNEs and thereby improve the competitiveness of their industries, such competition to attract FDI is bound to increase. Given the increasing importance attached by governments to FDI as a source of technology, capital and 
employment, attracting and promoting the embeddedness of MNEs is a crucial part of industrial policy.

We have confirmed- in line with other studies - that there are significant perceived agglomeration economies. That is to say, inward FDI seems a cumulative mechanism, in which past flows influence current and future flows into the host economy. This implies that countries and regions that already attract FDI are those most likely to continue to do so. There is significant anecdotal and empirical evidence that indicates that attracting a certain large initial investment is often magnified at a later stage, as it increases the probability of attracting subsequent investments. Governments often try and target foreign firms with incentive programs (see e.g., Mudambi, 1995; Mortimore and Vergara, 2004; Mytelka and Barclay, 2004) hoping that these firms will then act as "magnets" for additional foreign investments into a region or country.

However, such incentive programmes do not always work for relatively underdeveloped regions. It is likely that a certain threshold of foreign firms needs to be reached before the agglomeration effect kicks in. Subsidising sufficient FDI into such regions to encourage spontaneous additional investments may not always be economically viable or even affordable. Furthermore, even where FDI is attracted, it is not always the case that domestic firms will be able to benefit from the externalities that derive from MNE activity. As this study has shown, domestic and foreign firms can show different locational preferences. Although our data prevent us from confirming this, other studies (see e.g., Narula and Marin, 2003) have shown that this may be exacerbated by the fact that local firms in backward regions do not always possess adequate absorptive capacities to efficiently internalise such spillovers. The point that we are trying to make is that it is one thing to successfully attract FDI, it is a completely different challenge to embed the MNE affiliate in the local economy. 
Although only confirmed for holding companies (and this largely reflects limitations in our data), other studies have also shown that it is important that policy makers recognise that the benefits from FDI vary by the kinds of activities undertaken by affiliates in foreign locations (Narula and Dunning, 2000). Affiliates can have widely different roles, ranging from simple distribution tasks to having responsibility for a range of activities including production and $\mathrm{R} \& \mathrm{D}$. The scope of activities undertaken at a foreign location is tempered by locational characteristics (Benito et al., 2003; Holm et al., 2003). That is, the motive and nature of the value adding activity of the subsidiary require different location-specific complementary assets. This is reinforced by another important finding of this paper that EU investors show different locational preferences than Japanese and US-owned firms. MNEs from neighbouring countries tend to show a more sophisticated choice, reflecting their more clearly defined EU-wide focus, as compared to ‘foreign’ MNEs who may not have as well-developed a rationalised EU strategy.

These findings point to the need for governments to customise the nature of the specialised created assets they provide, depending on the kinds of FDI they wish to attract. Simply competing for FDI through incentives is an uncertain process with uncertain returns. Often, there is a tendency to overbid, resulting in welfare loss (Blomström, 2002). A more viable strategy would be to create an overall attractive business environment which is attractive to both local and foreign firms (low taxes, good infrastructure, access to EU markets, continuous improvements in labour skills), as the examples of Ireland, Sweden, and the Netherlands (Blomström, 2002; Hogenbirk, 2002) have shown.

It is imperative that governments see FDI promotion policies as an integral part of their industrial policy (Narula, 2003). It is obvious that governments have a strong interest in the ability of firms in a given location to conduct competitiveness-enhancing activities, and particularly those associated with the creation and deployment of knowledge capital. By promoting the wealth 
creating assets of its firms, and maintaining and improving indigenous resources and capabilities, governments can help maintain and improve their own locational attractiveness to mobile and footloose investors conducting higher value adding activity. It is essential that the development of location specific assets (both domestic sector competence and infrastructure) and the attraction of FDI are seen as two sides of the same coin, since the presence of highly competitive firms at a given location acts as a location advantage to MNEs, often prompting a virtuous circle. Conversely, strong location advantages, such as the presence of support institutions and firms, infrastructure and skilled manpower will enhance the ownership advantages of firms - whether domestic or foreign- located there, and will attract further FDI. 


\section{References}

Agarwal, J., "Determinants of Foreign Direct Investment: A Survey," Weltwirtschaftliches Archiv, 1980, 116 (4), pp. 739-773.

Barrell, R., and Pain, N., "Domestic Institutions, Agglomerations and Foreign Direct Investment in Europe," European Economic Review, 1999, 43 (4-6), pp. 925-934.

Bartik, T. J., "Business Location Decisions in the United States: Estimates of the Effects of Unionization, Taxes, and Other Characteristics of States," Journal of Business and Economic Statistics, 1985, 3 (1), pp. 14-22.

Benito, G.R.G., Grøgaard, B., and Narula, R., "Environmental Influences on MNE Subsidiary Roles: Economic Integration and the Nordic Countries," Journal of International Business Studies, 2003, 34 (5), pp. 443-456.

Blomström, M., "The Economics of International Investment Incentives," International Investment Perspectives, OECD, 2002, pp. 165-183

Boeckhout, I. J., Verhoeff, B. M., and Verster, A. C. P., "De Randstad als vestigingsplaats voor internationaal georiënteerde bedrijvigheid," Economisch-Statistische Berichten,1987, (212), pp. 1138-1145.

Braunerhjelm, P., and Svensson, R., "Host Country Characteristics and Agglomeration in Foreign Direct Investment," Applied Economics, 1996, 28 (7), pp. 833-840.

Caniels, M.C.J., and Romijn, H.A., "Agglomeration Advantages and Capability Building in Industrial Clusters: The Missing Link," Journal of Development Studies, 2003, 39 (3) pp. 129-154. 
Carlton, D. W., "The Location and Employment Choices of New Firms: An Econometric Model with Discrete and Continuous Endogenous Variables," The Review of Economics and Statistics, 1983, 65 (3), pp. 440-449.

CBS, Bedrijven in Nederland, Voorburg/Heerlen: Centraal Bureau voor de Statistiek. 1997.

Cheng, L.K., and Kwan, Y.K., "What are the Determinants of the Location of Foreign Direct Investment? The Chinese Experience," Journal of International Economics, 2000, 51 (2), pp. 379-400.

Deichmann, J., Karidis, S., and Sayek, S., "Foreign Direct Investment in Turkey: Regional Determinants," Applied Economics, 2003, 35 (16), pp. 1767-1778.

DNB, "Bijzondere financiële instellingen in Nederland", Statistisch Bulletin, 2000a (maart), pp. $19-28$.

Dunning, J. H., Multinational Enterprises and the Global Economy. Wokingham: AddisonWesley, 1993.

Dunning, J. H., "Re-evaluating the Benefits of Foreign Direct Investment", Transnational Corporations, 1994, 3 (1), pp. 23-51.

Friedman, J., Gerlowski, D. A., and Silberman, J., "What Attracts Foreign Multinational Corporations? Evidence from Branch Plant Location in the United States," Journal of Regional Science, 1992, 32 (4), pp. 403-418.

Head, K., Ries, J., and Swenson, D., "Agglomeration Benefits and Location Choice: Evidence from Japanese Manufacturing Investments in the United States," Journal of International Economics, 1995, 38 (3-4), pp. 223-247.

Hogenbirk, A.E., Determinants of Inward Foreign Direct Investment: The Case of the Netherlands, Maastricht, 2002. 
Holm, U., Malmberg, A., and Solvell, A., "Subsidiary Impact on Host-Country Economies - The Case of Foreign-Owned Subsidiaries Attracting Investment into Sweden," Journal of Economic Geography, 2003, 3 (4), pp. 389-408.

Kittiprapas, S., and McCann, P., "Industrial Location Behaviour and Regional Restructuring within the Fifth 'Tiger' Economy: Evidence from the Thai Electronics Industry," Applied Economics, 1999, 31 (1), pp. 37-51.

Krugman, P., Geography and Trade. Cambridge MA.: MIT Press, 1991.

Marshall, A., Principles of Economics. (8th ed.). London: MacMillan, 1920.

Martin, S., "Direct Foreign Investment in the United States," Journal of Economic Behavior and Organization, 1991, 16 (3), pp. 283-293.

McFadden, D., "Conditional Logit Analysis of Qualitative Choice Behavior," in P. Zarembka (Ed.), Frontiers in Econometrics (pp. 105-142). New York: Academic Press Inc., 1974.

McFadden, D., "Modelling the Choice of Residential Location," in A. Karlqvist, L. Lundqvist, F. Snickars, and J. W. Weibull (Eds.), Spatial Interaction Theory and Planning Models (pp. 75-96). Amsterdam: North Holland Publishing Company: 1978.

Mody, A., and Srinivasan, K., "Japanese and US Firms as Foreign Investors: Do They March to the Same Tune?," The Canadian Journal of Economics, 1998, 31 (4), pp. 778-799.

Mortimore, M., and Vergara, S., "Targetting winners: Can FDI policy help developing countries industrialize?,", European Journal of Development Research, forthcoming 2004.

Mudambi, R., "The MNE Investment Location Decision: Some Empirical Evidence," Managerial and Decision Economics, 1995, 16 (3), pp. 249-257.

Mytelka, L., and Barclay, L.A.,"Using Foreign Investment Strategically for Competence Building," European Journal of Development Research, forthcoming 2004. 
Narula, R., Globalisation and Technology: Interdependence, Innovation Systems and Industrial Policy, Cambridge: Polity Press: 2003.

Narula, R., and Dunning, J.H., "Industrial Development, Globalisation and Multinational Enterprises: New Realities for Developing Countries," Oxford Development Studies, 2000, 28 (2), pp. 141-167.

Narula, R., and Marin, A., "FDI Spillovers, Absorptive Capacities and the Nature of MNEs Firm-Specific-Assets: Evidence from Argentina," MERIT Research memorandum 200316, 2003.

Pinch, S., Henry, N., Jenkins, M., and Tallman, S., "From 'Industrial Districts' to 'Knowledge Clusters': A Model of Knowledge Dissemination and Competitive Advantage in Industrial Agglomerations," Journal of Economic Geography, 2003, 3 (4) pp. 373-388.

Schneider, F., and Frey, B. S., "Economic and Political Determinants of Foreign Direct Investment," World Development, 1985, 13 (2), pp. 161-175.

Shaver, J. M., "Do Foreign-Owned and US-Owned Establishments Exhibit the Same Location Pattern in the US Manufacturing Industries?," Journal of International Business Studies, 1998, 29 (3), pp. 469-492.

Wheeler, D., and Mody, A., "International Investment Location Decisions: The Case of US Firms," Journal of International Economics, 1992, 33 (1/2), pp. 57-76.

Woodward, D. P., "Locational Determinants of Japanese Manufacturing Start-ups in the United States", Southern Economic Journal, 1992, 58 (3), pp. 690-708.

Wu, X., and Strange, R., "The Location of Foreign Insurance Companies in China," International Business Review, 2000, 9 (3), pp. 383-398.

Yih Yun Yang, J. and Groenewold, N., "The Determinants of Foreign Direct Investment in Australia," Economic Record, 2000, 76 (232), pp. 45-54. 
Zhang, L., "Location-Specific Advantages and Manufacturing Direct Investment in South China," World Development, 1994, 2 (1), pp. 45-53. 


\section{Appendix}

To analyse Dutch Inward Foreign Direct Investment at the micro-level we have collected information on all known affiliates that started activities in the Netherlands in the period up to $1997^{30}$ and are still in business. For all firms the database reports their location in the Netherlands, their main SIC-activity, the year of establishment (and occasionally of take-over), number of employees, and identity and home country of the parent. Each affiliate is counted as one observation.

We acknowledge the fact that lists of firms are never exhaustive, up-to-date, and fully accurate. We, therefore, have combined several sources to make the database as extensive as possible.

First of all, we have used the 1996 and 1997 Dun \& Bradstreet CDs to locate a large number of foreign firms conducting activities in the Netherlands. These addresses have been updated using the printed version of Dun's “foreign firms in the Netherlands 1999”. Furthermore, the database has been complemented by firms listed in the ABC-Directory of Firms (1999). Japanese firms listed by JETRO were also included. To check the information achieved in this way, we traced all firms in our list on the 1999 REACH-A database (review and analysis of companies in Holland). That way, missing data were added and locations and activities were verified. This search resulted in a database of 7484 foreign establishments, employing at least 372428 people $e^{\mathrm{xxii}}$. 
Table 1 Overview of the finding of empirical studies on the determinants of location choice

\begin{tabular}{|c|c|c|c|c|c|c|c|c|c|c|c|c|c|c|c|c|}
\hline Study & \multicolumn{3}{|c|}{1} & 2 & 3 & \multicolumn{3}{|c|}{4} & \multicolumn{4}{|c|}{5} & 6 & 7 & 8 & 9 \\
\hline Country & \multicolumn{3}{|c|}{ US } & US & US & \multicolumn{3}{|c|}{ US } & \multirow{2}{*}{\multicolumn{4}{|c|}{$\begin{array}{c}\text { US } \\
\text { JP }\end{array}$}} & US & $\mathrm{CN}$ & $\mathrm{CN}$ & $\mathrm{TH}$ \\
\hline Home country of investing firms & \multicolumn{3}{|c|}{ US } & US & $*$ & ** & JP & EU & & & & & JP & $* *$ & $* *$ & \\
\hline Industry & A & B & $\mathrm{C}$ & $\mathrm{D}$ & & & & & & & & & $\mathrm{D}$ & & $E$ & $\mathrm{~F}$ \\
\hline Number of regions & 39 & 24 & 26 & All & 50 & & & & $\begin{array}{c}36 \\
\text { States } \\
\end{array}$ & $\begin{array}{c}10 \\
\text { counties }\end{array}$ & I & II & $\begin{array}{c}34 \\
\text { states } \\
\end{array}$ & 29 & $\begin{array}{c}6 \\
\text { cities } \\
\end{array}$ & $\begin{array}{c}4 \\
\text { regions }\end{array}$ \\
\hline $\begin{array}{l}\text { A. Agglomeration variables } \\
\text { Existing manufacturing activity } \\
\text { Man-hours in production } \\
\text { Gross state product } \\
\text { Per capita income } \\
\text { Agglomeration manuf. firms } \\
\text { Agglomeration of foreign firms } \\
\text { Agglomeration of keiretsu firms } \\
\text { B. Market variables } \\
\text { Market size } \\
\text { Market destination of local sales } \\
\text { C. Labour variables } \\
\text { Man hours in production } \\
\text { Unionisation } \\
\text { Productivity } \\
\text { Skills level of employees } \\
\text { Wage rate } \\
\text { Number of engineers } \\
\text { Poverty level } \\
\text { Unemployment rate } \\
\text { Education level of population } \\
\text { Population density } \\
\text { D. Government policy } \\
\text { Corporate tax } \\
\text { Property tax } \\
\text { Domestic unitary tax } \\
\text { Worldwide unitary tax } \\
\text { Local taxes } \\
\text { Home country support office } \\
\text { State effort } \\
\text { (attraction programs/budget) } \\
\text { Proximity to Gov. institutes }\end{array}$ & $\begin{array}{c}\text { NS } \\
- \\
+\end{array}$ & $\begin{array}{c}\text { NS } \\
+\end{array}$ & $\begin{array}{c}\text { NS } \\
\text { NS } \\
-\end{array}$ & $\begin{array}{c} \\
\\
- \\
\text { NS } \\
+ \\
+ \\
\text { NS }\end{array}$ & $\begin{array}{c}+ \\
\text { NS }\end{array}$ & $\begin{array}{l}+ \\
+\end{array}$ & $\begin{array}{l}+ \\
+ \\
+\end{array}$ & $\begin{array}{l}\text { NS } \\
\text { NS } \\
\text { NS }\end{array}$ & $\begin{array}{c}\text { NS } \\
- \\
- \\
+ \\
\text { NS }\end{array}$ & $\begin{array}{c}+ \\
\text { NS } \\
- \\
- \\
\text { NS } \\
+\end{array}$ & $\begin{array}{c}\text { NS } \\
\text { NS } \\
\text { NS } \\
- \\
+ \\
\text { NS }\end{array}$ & $\begin{array}{c}- \\
\text { NS } \\
\text { NS } \\
+\end{array}$ & $\begin{array}{l}+ \\
+\end{array}$ & 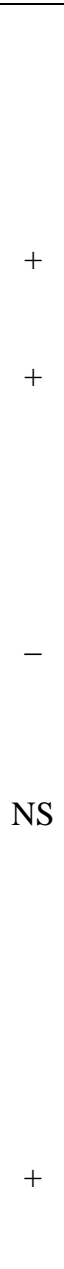 & 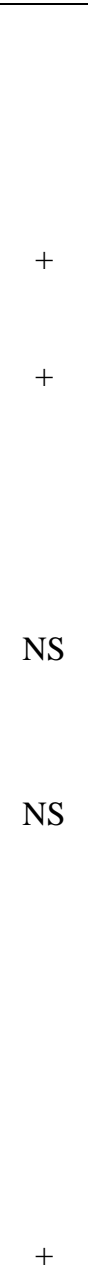 & + \\
\hline
\end{tabular}


Table 1 Overview of the finding of empirical studies on the determinants of location choice (continued)

\begin{tabular}{|c|c|c|c|c|c|c|c|c|c|c|c|c|c|c|c|c|}
\hline $\begin{array}{l}\text { E. Infrastructure } \\
\text { Electricity price (energy costs) } \\
\text { Road miles } \\
\text { Interstate connection } \\
\text { F. Geographic variables } \\
\text { Land area } \\
\text { Geographic location } \\
\text { (coastal areas) } \\
\end{array}$ & - & - & - & $\begin{array}{l}\text { NS } \\
\text { NS } \\
+ \\
+\end{array}$ & + & $\begin{array}{c}\text { NS } \\
+\end{array}$ & $\begin{array}{l}- \\
+\end{array}$ & - & + & $\begin{array}{l}+ \\
+\end{array}$ & $\begin{array}{l}+ \\
+\end{array}$ & $\begin{array}{c}\text { NS } \\
+\end{array}$ & & + & & \\
\hline Number of observations & 290 & 84 & 153 & 1067 & 50 & 884 & 338 & 440 & 540 & 540 & 250 & 290 & 751 & & 138 & 115 \\
\hline - Loglikelihood value (E3) & 1.5 & 3.8 & 7.5 & & & 1.7 & 0.6 & 0.9 & 1.8 & 0.9 & 0.4 & 0.4 & 2.2 & & 0.2 & \\
\hline
\end{tabular}

\section{Study}

1 = Carlton (1983)

$4=$ Friedman et al. (1992)

7 = Cheng and Kwan (2000)

$$
\begin{aligned}
& 2=\text { Bartik (1985) } \\
& 5=\text { Woodward (1992) } \\
& 8=\text { Wu and Strange }(2000)
\end{aligned}
$$

$\mathrm{JP}=$ Japan

$\mathrm{EU}=$ European Union

$\mathrm{B}=$ Communication transmission equipment

$\mathrm{E}=$ Insurance
$3=$ Shaver $(1998)$

$6=$ Head et al. (1995)

9 = Kittiprapas and McCann (1999)

US = United States

$\mathrm{TH}=$ Thailand

\section{Industry}

A = Plastic products

$\mathrm{D}=$ All manufacturing (SIC 20-39)

$\mathrm{C}=$ Electronic components

$\mathrm{F}=$ Electronics

\section{Region}

$\mathrm{I}=$ Auto Alley

$\mathrm{II}=$ Non auto alley

Home country of investment

* All foreign

** Japan, West Germany, United Kingdom, Canada, Switzerland, France, Netherlands, other

Notes

NS = No significant influence on location choice

$+=$ Increased probability of choice for a particular location

- = Decreased probability of choice for a particular location 
Table 2 Counts and home countries of new foreign establishments in the Netherlands

\begin{tabular}{|c|c|c|c|c|c|}
\hline Country & 1995-1996 & $1992-1996$ & Country & 1995-1996 & 1992-1996 \\
\hline Aruba & & 1 & Liechtenstein & \multirow{9}{*}{4} & 1 \\
\hline Australia & 3 & 15 & Luxembourg & & 30 \\
\hline Austria & 4 & 11 & Malaysia & & 2 \\
\hline Belgium & 47 & 146 & Mexico & & 1 \\
\hline Brazil & & 1 & New Zealand & & 1 \\
\hline Canada & 3 & 16 & Norway & & 4 \\
\hline Denmark & 7 & 20 & Philippines & & 1 \\
\hline Fed. Rep. Germany & 54 & 239 & Portugal & & 3 \\
\hline Finland & 2 & 5 & Russian Fed. & & 1 \\
\hline France & 23 & 58 & Singapore & \multirow[t]{2}{*}{1} & 5 \\
\hline Georgië & & 1 & South Africa & & 1 \\
\hline Hong Kong & \multirow[t]{4}{*}{1} & 8 & Spain & 5 & 14 \\
\hline Hungary & & 1 & Surinam & 1 & 1 \\
\hline India & & 2 & Sweden & 7 & 28 \\
\hline Indonesia & & 1 & Switzerland & 9 & 58 \\
\hline Ireland & 4 & 26 & Taiwan & \multirow[t]{2}{*}{2} & 16 \\
\hline Israel & 4 & 17 & Turkey & & 2 \\
\hline Italy & 5 & 35 & UAE & 1 & 1 \\
\hline Japan & 17 & 81 & United Kingdom & 71 & 263 \\
\hline Republic of Korea & 3 & 9 & United States & 79 & 309 \\
\hline \multicolumn{4}{|l|}{ Total new } & 357 & 1435 \\
\hline
\end{tabular}

Source: DutchInvest database 
Table 3 Dutch establishment patterns of local and foreign firms per region, 1995

\begin{tabular}{|l|r|r|r|r|}
\hline Region & Foreign & Share of all foreign (\%) & Local & Share of all local (\%) \\
\hline Groningen & 61 & 0,9 & 21754 & 3,3 \\
Friesland & 35 & 0,5 & 27065 & 4,1 \\
Drenthe & 47 & 0,7 & 19258 & 2,9 \\
Overijssel & 171 & 2,4 & 45639 & 7,0 \\
Gelderland & 535 & 7,6 & 81435 & 12,5 \\
Utrecht & 667 & 9,4 & 45228 & 6,9 \\
Noord Holland & 2286 & 32,4 & 110589 & 16,9 \\
Zuid Holland & 1775 & 25,1 & 129060 & 19,8 \\
Zeeland & 67 & 0,9 & 18163 & 2,8 \\
Noord Brabant & 1033 & 14,6 & 99387 & 15,2 \\
Limburg & 303 & 4,3 & 45502 & 7,0 \\
Flevoland & 79 & 1,1 & 10151 & 1,6 \\
\hline
\end{tabular}

$\left(\chi_{11}^{2}=2158, \mathrm{p}<0.0001\right)$ 
Table 4 Explanatory variables

\begin{tabular}{|l|l|c|l|}
\hline Variable & Definition & $\begin{array}{c}\text { Hypothesised } \\
\text { effect }\end{array}$ & Source \\
\hline Foreign agglomeration & $\begin{array}{l}\text { Ln (number of foreign establishments) } \\
\text { Local agglomeration }\end{array}$ & + & Dn (number of local establishments) \\
Market size & Ln (Gross National Product of region) & + & CBS \\
Population density & Ln (population per km²) & + & CBS \\
Unemployment rate & Average unemployment rate per region & $?$ & CBS \\
Real estate taxes & Ln (amount of real estate taxes per & - & CBS \\
individual firm) & + & CBS \\
Infrastructure & Ln (roads per km² land area) & + & CBS \\
Cand area & Ln (Land Area in km²) & & DutchInvest \\
Sector dummy dummy & Dummy for establishments from particular & & \\
& countries (EU, US, Japan) & & DutchInvest \\
\hline
\end{tabular}


Table 5 Regression results

\begin{tabular}{|c|c|c|c|c|c|c|c|c|}
\hline Specification & 1 & 2 & 3 & 4 & 5 & 6 & 7 & 8 \\
\hline Years & \multicolumn{2}{|c|}{ 1995-1996 } & \multicolumn{2}{|c|}{ 1992-1996 } & \multicolumn{2}{|c|}{ 1995-1996 } & \multicolumn{2}{|c|}{ 1992-1996 } \\
\hline Regions & \multicolumn{4}{|c|}{ Randstad or not } & \multicolumn{4}{|c|}{12 Provinces } \\
\hline Constant & $\begin{array}{l}17.8^{* * *} \\
(5.84)\end{array}$ & $\begin{array}{r}-159.1^{* * *} \\
(37.81)\end{array}$ & $\begin{array}{r}14.58^{* * *} \\
(2.81)\end{array}$ & $\begin{array}{r}23.70 \\
(22.78)\end{array}$ & & & & \\
\hline Local agglomeration & $\begin{array}{l}-7.12^{* * *} \\
\quad(1.10)\end{array}$ & $\begin{array}{r}-36.2^{* * *} \\
(6.45)\end{array}$ & $\begin{array}{r}-5.94^{* * *} \\
(0.49)\end{array}$ & $\begin{array}{r}19.49^{* * *} \\
(5.88)\end{array}$ & $\begin{array}{r}0.24 \\
(0.23)\end{array}$ & $\begin{array}{r}-1.66 \\
(1.63)\end{array}$ & $\begin{array}{r}-0.04 \\
(0.11)\end{array}$ & $\begin{array}{r}-0.09 \\
(0.13)\end{array}$ \\
\hline Foreign agglomeration & $\begin{array}{l}9.01^{* * *} \\
(1.14)\end{array}$ & $\begin{array}{l}8.01^{* * *} \\
(1.30)\end{array}$ & $\begin{array}{l}7.68^{* * *} \\
(0.50)\end{array}$ & $\begin{array}{l}5.44^{* * *} \\
(1.25)\end{array}$ & $\begin{array}{l}0.76^{* * *} \\
(0.12)\end{array}$ & $\begin{array}{r}0.82^{* * *} \\
(0.32)\end{array}$ & $\begin{array}{l}0.92^{* * *} \\
(0.06)\end{array}$ & $\begin{array}{r}0.96^{* * *} \\
(0.07)\end{array}$ \\
\hline Market size & & $\begin{array}{r}27.88^{* * *} \\
(5.57)\end{array}$ & & $\begin{array}{l}-9.17^{* *} \\
(4.05)\end{array}$ & & $\begin{array}{r}0.67 \\
(0.86)\end{array}$ & & $\begin{array}{r}0.38 \\
(0.77)\end{array}$ \\
\hline Population density & & & & & & $\begin{array}{r}1.46 \\
(1.88)\end{array}$ & & $\begin{array}{r}-0.63 \\
(0.98)\end{array}$ \\
\hline Infrastructure & & $\begin{array}{r}0.74 \\
(0.63)\end{array}$ & & & & $\begin{array}{r}0.03 \\
(1.11)\end{array}$ & & $\begin{array}{r}0.29 \\
(0.77)\end{array}$ \\
\hline Property tax & & & & & & $\begin{array}{r}-2.55 \\
(2.89)\end{array}$ & & $\begin{array}{r}0.59 \\
(1.64)\end{array}$ \\
\hline Unemployment & & $\begin{array}{l}0.58^{* *} \\
(0.29)\end{array}$ & $\begin{array}{r}0.18 \\
(0.25)\end{array}$ & & & & & $\begin{array}{r}-0.04 \\
(0.04)\end{array}$ \\
\hline Land area & & & $\begin{array}{r}-14.71^{* * *} \\
(2.36)\end{array}$ & & & $\begin{array}{r}1.12 \\
(1.31)\end{array}$ & & $\begin{array}{r}-0.14 \\
(0.73)\end{array}$ \\
\hline Manufacturing & & $\begin{array}{r}0.78 \\
(0.81)\end{array}$ & & & & & & \\
\hline Holding & & $\begin{array}{c}1.44^{*} \\
(0.87)\end{array}$ & $\begin{array}{c}1.06^{* * *} \\
(0.39)\end{array}$ & & & & & \\
\hline EU & & $\begin{array}{r}0.35 \\
(0.61)\end{array}$ & & & & & & \\
\hline US & & & $\begin{array}{l}0.85^{* *} \\
(0.31)\end{array}$ & & & & & \\
\hline Japan & & & $\begin{array}{c}1.22^{*} \\
(0.62)\end{array}$ & & & & & \\
\hline
\end{tabular}


Table 5 Regression results (continued)

\begin{tabular}{|c|c|c|c|c|c|c|c|c|}
\hline Specification & 1 & 2 & 3 & 4 & 5 & 6 & 7 & 8 \\
\hline Years & \multicolumn{2}{|c|}{ 1995-1996 } & \multicolumn{2}{|c|}{$1992-1996$} & \multicolumn{2}{|c|}{ 1995-1996 } & \multicolumn{2}{|c|}{ 1992-1996 } \\
\hline Regions & \multicolumn{4}{|c|}{ Randstad or not } & \multicolumn{4}{|c|}{12 Provinces } \\
\hline Log likelihood & -103.2 & -62.6 & -437.2 & -250.7 & -688.8 & -687.5 & -2733.6 & -2731.3 \\
\hline Restricted log likelihood & -245.73 & -245.7 & -978.2 & -977.3 & & & & \\
\hline$\chi^{2}$ & $285.1^{* * *}$ & $366.2^{* * *}$ & $1080.4^{* * *}$ & $1453.2^{* * *}$ & & & & \\
\hline Number of choosers & 357 & 357 & 1434 & 1434 & 357 & 357 & 1434 & 1434 \\
\hline Number of choices & 2 & 2 & 2 & 2 & 12 & 12 & 12 & 12 \\
\hline
\end{tabular}

Notes: standard errors are shown in parentheses

${ }^{* * *}$ significant at the 1 percent level, ${ }^{* *}$ at the 5 percent level, ${ }^{*}$ at the 10 percent level.

Variables that could not be tested due to multicollinearity problems are omitted from this table. 
Table 6 Hypotheses tests

\begin{tabular}{|cl|c|c|}
\hline \multirow{2}{*}{ Hypothesis } & \multicolumn{2}{|c|}{ Confirmed? } \\
\cline { 3 - 4 } & $\begin{array}{l}\text { The presence of foreign establishments in a region positively influences } \\
\text { new foreign investment in that region }\end{array}$ & Yes & Yes \\
\hline $2 \mathrm{a}$ & $\begin{array}{l}\text { The presence of local establishments in a region positively influences } \\
\text { new foreign investment in that region } \\
\text { The presence of local establishments in a region negatively influences } \\
\text { new foreign investment in that region }\end{array}$ & No & No \\
\hline 3 & $\begin{array}{l}\text { A larger market size in a region positively influences new foreign } \\
\text { investment in that region }\end{array}$ & Yes & No \\
\hline 4 & $\begin{array}{l}\text { A higher population density in a region positively influences new } \\
\text { foreign investments in that region }\end{array}$ & No \\
\hline $5 a$ & $\begin{array}{l}\text { Higher unemployment in a region negatively influences new foreign } \\
\text { investment in that region }\end{array}$ & No \\
\hline $5 b$ & $\begin{array}{l}\text { Higher unemployment in a region positively influences new foreign } \\
\text { investment in that region }\end{array}$ & No \\
\hline 6 & $\begin{array}{l}\text { Higher real estate property taxes in a region negatively influence new } \\
\text { foreign investment in that region }\end{array}$ & No \\
\hline 7 & $\begin{array}{l}\text { Larger infrastructural provisions in a region positively influence new } \\
\text { foreign investment in that region }\end{array}$ & Yes & No \\
\hline 8 & $\begin{array}{l}\text { A larger available area in a region positively influences new foreign } \\
\text { investment in that region }\end{array}$ & No & No \\
\hline 9 & $\begin{array}{l}\text { Multinationals from countries that have a border with the Netherlands } \\
\text { are more inclined to invest in regions that are attached to their home } \\
\text { country than firms from countries that are not direct neighbours }\end{array}$ & Yes & Yes \\
\hline
\end{tabular}

For this hypothesis we find significant results opposing the suggested relationship

\# not tested due to multicollinearity problems 
Table 7 New establishments per region of firms from different home countries (1992-96)

\begin{tabular}{|l|r|r|r|r|r|r|r|}
\hline Region & All & US & UK & Germany & Belgium & Japan & All Europe \\
\hline Groningen & 11 & 2 & 2 & $\mathbf{3}$ & 1 & 2 & 7 \\
Friesland & 13 & 2 & 5 & 3 & - & 1 & 9 \\
Drenthe & 14 & 5 & 2 & $\mathbf{5}$ & 1 & - & 8 \\
Overijssel & 32 & 6 & 4 & $\mathbf{1 2}$ & 3 & 2 & 21 \\
Gelderland & 104 & 20 & 15 & $\mathbf{3 2}$ & 12 & 2 & 72 \\
Utrecht & 145 & 42 & 21 & 31 & 10 & 7 & 81 \\
Noord Holland & 416 & 104 & 86 & 41 & 16 & 41 & 225 \\
Zuid Holland & 357 & 70 & 69 & 47 & 36 & 12 & 218 \\
Zeeland & 16 & 1 & 3 & 3 & $\mathbf{5}$ & - & 12 \\
Noord Brabant & 230 & 39 & 41 & $\mathbf{3 9}$ & $\mathbf{4 7}$ & 7 & 159 \\
Limburg & 71 & 16 & 8 & $\mathbf{1 5}$ & $\mathbf{1 3}$ & 5 & 47 \\
Flevoland & 26 & 2 & 7 & 8 & 2 & 2 & 19 \\
$\chi^{2}$ 9 & & NS & NS & $44.35^{*}$ & & & NS \\
$\chi^{2}{ }_{8}$ & & & & $54.23^{*}$ & & \\
\hline
\end{tabular}

${ }^{*}$ Significant at the 0.005 percent level, Neighbouring regions are shown in bold

$\chi^{2}$ tests can be applied if every cell has at least 1 observation and no more than $20 \%$ of the cells have less than five observations. To meet these requirements, we have grouped the observations in the Northern provinces Friesland, Groningen and Drenthe. The number of degrees of freedom is reduced to nine. For Belgium, we also combined Flevoland and Noord Holland. For Japan, too many aggregations are needed to allow for $\chi^{2}$ testing. 


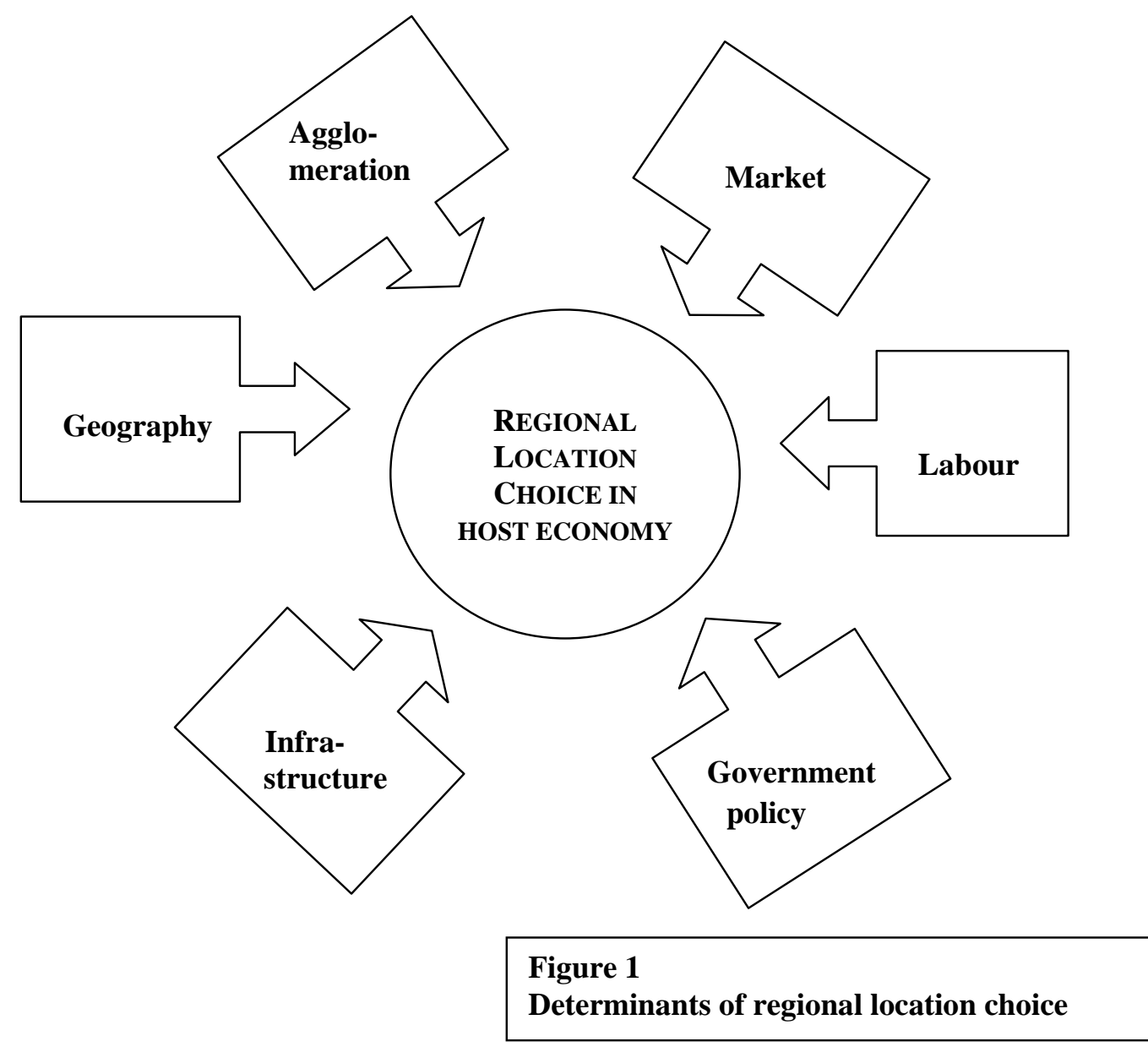




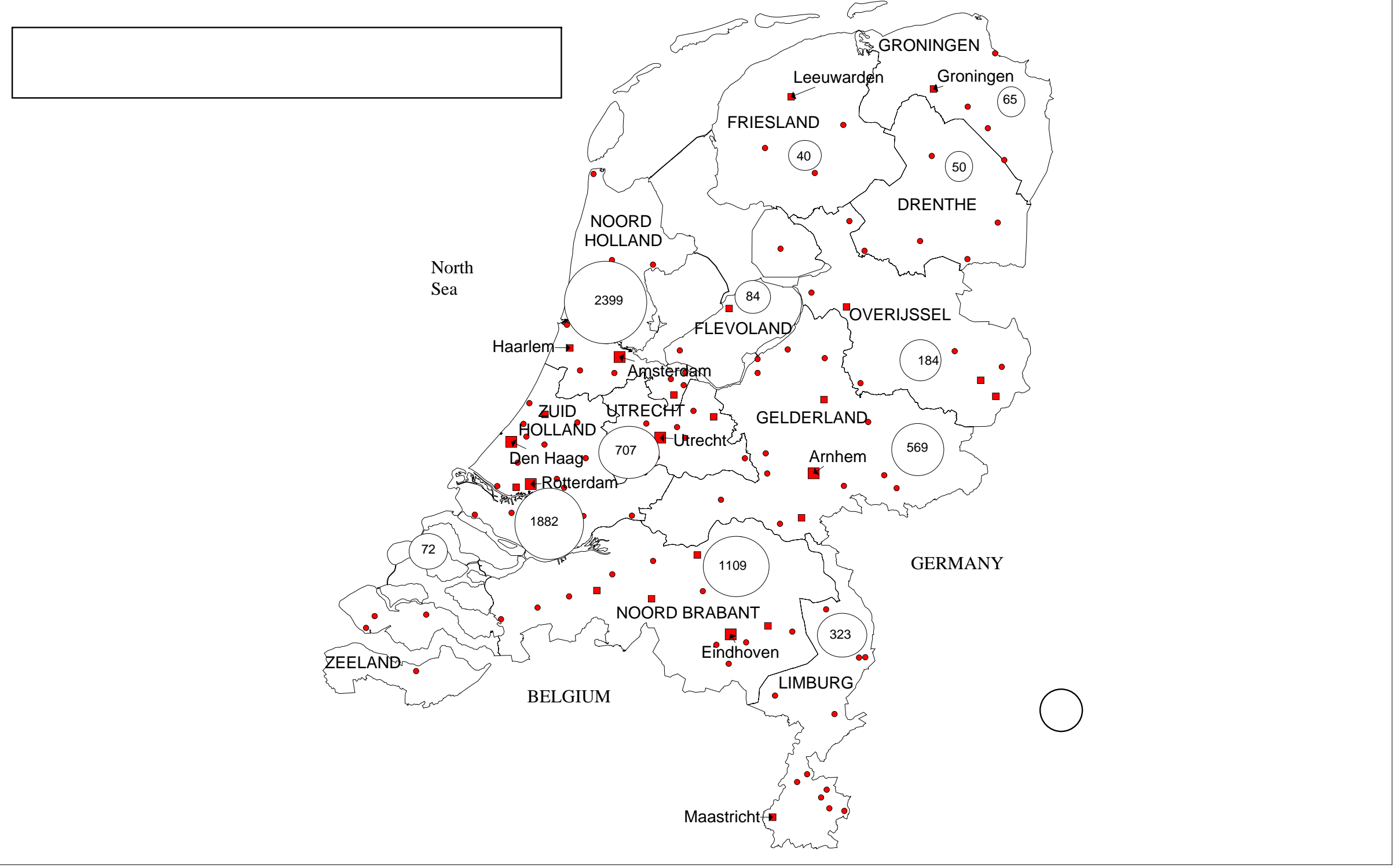




\section{Agglomeration}

H1: Foreign establishments

$\mathrm{H} 2$ : Local establishments

Market variables

H3: Market size

Labour variables

H4: Population density

H5: Unemployment

Government policy

H6: Property taxes

Infrastructural variables

$\mathrm{H} 7$ : Infrastructure

Geographic variables

H8: Area

H9: Border countries

(+)

$(+/-)$

(+)

(+)

$(+/-)$

(-)

(+)

(+)

(+)

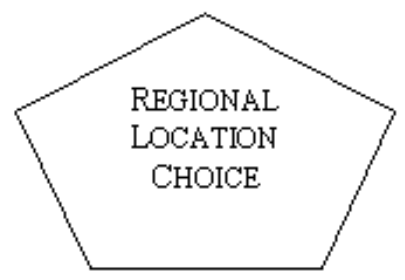

Figure 3

Hypothesised relationships 


\section{Notes}

${ }^{\mathrm{i}}$ Many of these studies analyse aggregated data and sometimes compare the choices between two or more countries or the changes in attractiveness of a particular country over time (see e.g., Agarwal, 1980; Deichmann et al., 2003; Martin, 1991; Mody and Srinivasan,1998; Schneider and Frey, 1985; Yih Yun Yang and Groenewold, 2000; and Zhang, 1994).

${ }^{\text {ii }}$ Carlton (1983) indicates that it is possible that energy is acting as a proxy for prices of other inputs which are heavily energy dependent or that the technology of new firms is more energy intensive than that of existing firms in the industry.

iii This result implies that regions with high taxes are unattractive for new manufacturing establishments and high taxes therefore discourage new plants (Bartik, 1985).

iv Shaver (1998) emphasises that coastal areas likely enjoy transportation cost advantages when receiving imports from abroad compared to inland regions, making the economic benefit of location near the coast greater for foreign firms using those imports than for U.S. firms. ${ }^{\mathrm{v}}$ Friedman et al. (1992) find that unionisation positively influences the choice for a US state. They suspect that the decline in power of the unions in the 1980s may have diminished the foreign firms' avoidance of states with higher unionisation rates. This result opposes the results of Bartik (1985) and Shaver (1998) who find that unionisation significantly reduces the attractiveness of a state.

${ }^{\mathrm{vi}}$ Woodward (1992) analyses both the choice for a particular state in the US (36 states were included that actually had Japanese establishments) and the choice for a particular county within the state. In the later case, this choice is compared to the characteristics of 9 alternative, surrounding counties. 
${ }^{\text {vii }}$ Cheng and Kwan (2000) estimate the locational determinants within a Generalized Method of Moments (GMM) framework. Contrary to the other studies mentioned in Table 1 their dependent variable is the stock of FDI in the host region and not the actual establishment counts.

viii Wheeler and Mody (1992), Braunerhjelm and Svensson (1996), and Barrell and Pain (1999) are not mentioned in Table 1 because these studies analyse the characteristics of several host countries and not regions within one host country.

ix Braunerhjelm and Svensson (1996) emphasise that both knowledge spillovers and "pecuniary" externalities - associated with demand and supply linkages, such as the possibility to use joint networks of suppliers and distributors - make up the most important agglomeration benefits. ${ }^{\mathrm{x}}$ Barrell and Pain (1998) suggest that agglomeration economies arise from the presence of other firms in the region and the resulting business linkages, and the associated availability of skilled labour.

${ }^{x i}$ Most location studies include unionisation of the region (Bartik, 1985; Carlton, 1983) as one of the labour-market variables but this is irrelevant in the Dutch situation. Unionisation is organised per industry rather than per region. Furthermore, regional data on differences in wages, skills and education level, productivity, and poverty are not available for the Netherlands and therefore have to be excluded. It is quite likely that within a small geographic area like the Netherlands these variations would be small and disregarding this variable should not cause a lot of problems. ${ }^{\text {xii }}$ In this study 'better' means more roads per $\mathrm{km}^{2}$ area.

xiii This choice is dictated by the available data. For each MNE active in the Netherlands, the DutchInvest-database reports data on the city and province where the affiliate is located. Every affiliate is counted as one observation. Given that no data are available that indicate the size of the investment (either the initial investment or current size in terms of total assets or employment) we are forced to treat all affiliates in the same way. We know which Dutch 
province they have favoured for their activities, even though the other 11 provinces in the Netherlands would have been alternative locations. The choice for a region given the existence of alternative regions can be modelled using conditional logit. For each observation (in this case for each affiliate), the chosen region (province) is given the value 1 , while the 11 alternative regions are 0.

${ }^{\text {xiv }} \varepsilon_{\mathrm{jt}}$ reflects the unique advantages of province j to company t. It differs across countries for any one firm and across firms for any one country (Carlton, 1983).

${ }^{\mathrm{xv}}$ If only two choices are considered $(\mathrm{J}=2)$ the model reduces to a binary discrete choice model. ${ }^{\text {xvi }}$ Alternatively, we can follow an adaptation of the McFadden-model as discussed by Head et al. (1995). Following this model avoids having to specify all individual regional characteristics, such as wages, unionisation rates, energy prices, and access to ports. A possible problem with that approach stems from the near impossibility of selecting and correctly measuring all relevant sectoral variables. Instead, Head et al. (1995) only consider agglomeration. In this study we use both specifications. We model location choice considering only agglomeration of local and foreign firms, but also specify individual characteristics of the region for each of the six groups of variables, in an attempt to capture the significance of individual regional attractions.

${ }^{\text {xvii }}$ We have counted each Dutch affiliate of a foreign firm as one establishment if it is registered as a private limited company (B.V.) or is reported as an independent company in the Dun and Bradstreet database. We have only considered those Dutch establishments whose ultimate owner is a foreign firm and have not taken firms into account whose ultimate owner is a Dutch affiliate of a foreign firm.

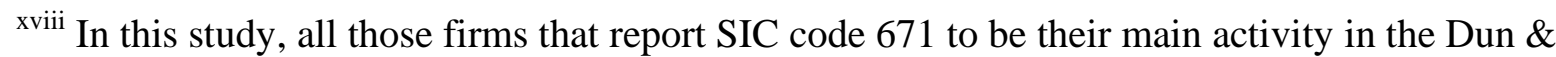
Bradstreet reports are classified as holdings. Usually they employ only one or a few people. 
${ }^{\text {xix }}$ Highly correlated variables include local and foreign agglomeration, both agglomeration variables and market size, local agglomeration and area, and foreign agglomeration and property taxes.

${ }^{\mathrm{xx}}$ Infrastructure $\beta=22.9^{* * *}(\mathrm{SE}=4.9)$.

${ }^{x x i} \mathrm{EU} \beta=-0.50^{* *}(\mathrm{SE}=0.23)$.

${ }^{\text {xxii }}$ For more than 90 percent of all foreign establishments in the Netherlands employment data are available. It is reasonable to assume that all the other firms employ at least one person. On average the establishments employ 55 people, which would increase total employment in foreign firms to over 400000. 
Table 1 Overview of the finding of empirical studies on the determinants of location choice

\begin{tabular}{|c|c|c|c|c|c|c|c|c|c|c|c|c|c|c|c|c|}
\hline Study & \multicolumn{3}{|c|}{1} & 2 & 3 & \multicolumn{3}{|c|}{4} & \multicolumn{4}{|c|}{5} & 6 & 7 & 8 & 9 \\
\hline Country & \multicolumn{3}{|c|}{ US } & US & US & \multicolumn{3}{|c|}{ US } & \multirow{2}{*}{\multicolumn{4}{|c|}{$\begin{array}{c}\text { US } \\
\text { JP }\end{array}$}} & US & $\mathrm{CN}$ & $\mathrm{CN}$ & $\mathrm{TH}$ \\
\hline Home country of investing firms & \multicolumn{3}{|c|}{ US } & US & $*$ & ** & JP & EU & & & & & JP & $* *$ & $* *$ & \\
\hline Industry & A & B & $\mathrm{C}$ & $\mathrm{D}$ & & & & & & & & & $\mathrm{D}$ & & $E$ & $\mathrm{~F}$ \\
\hline Number of regions & 39 & 24 & 26 & All & 50 & & & & $\begin{array}{c}36 \\
\text { States } \\
\end{array}$ & $\begin{array}{c}10 \\
\text { counties }\end{array}$ & I & II & $\begin{array}{c}34 \\
\text { states } \\
\end{array}$ & 29 & $\begin{array}{c}6 \\
\text { cities } \\
\end{array}$ & $\begin{array}{c}4 \\
\text { regions }\end{array}$ \\
\hline $\begin{array}{l}\text { A. Agglomeration variables } \\
\text { Existing manufacturing activity } \\
\text { Man-hours in production } \\
\text { Gross state product } \\
\text { Per capita income } \\
\text { Agglomeration manuf. firms } \\
\text { Agglomeration of foreign firms } \\
\text { Agglomeration of keiretsu firms } \\
\text { B. Market variables } \\
\text { Market size } \\
\text { Market destination of local sales } \\
\text { C. Labour variables } \\
\text { Man hours in production } \\
\text { Unionisation } \\
\text { Productivity } \\
\text { Skills level of employees } \\
\text { Wage rate } \\
\text { Number of engineers } \\
\text { Poverty level } \\
\text { Unemployment rate } \\
\text { Education level of population } \\
\text { Population density } \\
\text { D. Government policy } \\
\text { Corporate tax } \\
\text { Property tax } \\
\text { Domestic unitary tax } \\
\text { Worldwide unitary tax } \\
\text { Local taxes } \\
\text { Home country support office } \\
\text { State effort } \\
\text { (attraction programs/budget) } \\
\text { Proximity to Gov. institutes }\end{array}$ & $\begin{array}{c}\text { NS } \\
- \\
+\end{array}$ & $\begin{array}{c}\text { NS } \\
+\end{array}$ & $\begin{array}{c}\text { NS } \\
\text { NS } \\
-\end{array}$ & $\begin{array}{c} \\
\\
- \\
\text { NS } \\
+ \\
+ \\
\text { NS }\end{array}$ & $\begin{array}{c}+ \\
\text { NS }\end{array}$ & $\begin{array}{l}+ \\
+\end{array}$ & $\begin{array}{l}+ \\
+ \\
+\end{array}$ & $\begin{array}{l}\text { NS } \\
\text { NS } \\
\text { NS }\end{array}$ & $\begin{array}{c}\text { NS } \\
- \\
- \\
+ \\
\text { NS }\end{array}$ & $\begin{array}{c}+ \\
\text { NS } \\
- \\
- \\
\text { NS } \\
+\end{array}$ & $\begin{array}{c}\text { NS } \\
\text { NS } \\
\text { NS } \\
- \\
+ \\
\text { NS }\end{array}$ & $\begin{array}{c}- \\
\text { NS } \\
\text { NS } \\
+\end{array}$ & $\begin{array}{l}+ \\
+\end{array}$ & 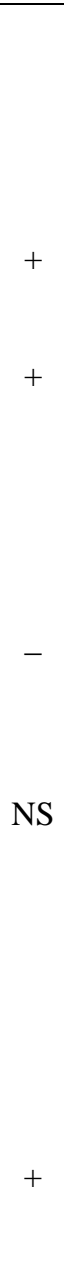 & 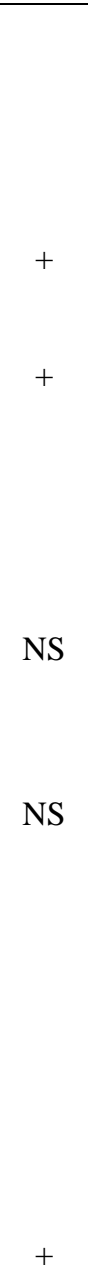 & + \\
\hline
\end{tabular}


Table 1 Overview of the finding of empirical studies on the determinants of location choice (continued)

\begin{tabular}{|c|c|c|c|c|c|c|c|c|c|c|c|c|c|c|c|c|}
\hline $\begin{array}{l}\text { E. Infrastructure } \\
\text { Electricity price (energy costs) } \\
\text { Road miles } \\
\text { Interstate connection } \\
\text { F. Geographic variables } \\
\text { Land area } \\
\text { Geographic location } \\
\text { (coastal areas) }\end{array}$ & - & - & - & $\begin{array}{l}\text { NS } \\
\text { NS } \\
+ \\
+\end{array}$ & + & $\begin{array}{c}\text { NS } \\
+\end{array}$ & $\begin{array}{l}- \\
+\end{array}$ & - & + & $\begin{array}{l}+ \\
+\end{array}$ & $\begin{array}{l}+ \\
+\end{array}$ & $\begin{array}{c}\text { NS } \\
+\end{array}$ & & + & & \\
\hline Number of observations & 290 & 84 & 153 & 1067 & 50 & 884 & 338 & 440 & 540 & 540 & 250 & 290 & 751 & & 138 & 115 \\
\hline - Loglikelihood value (E3) & 1.5 & 3.8 & 7.5 & & & 1.7 & 0.6 & 0.9 & 1.8 & 0.9 & 0.4 & 0.4 & 2.2 & & 0.2 & \\
\hline
\end{tabular}

\section{Study}

1 = Carlton (1983)

$4=$ Friedman et al. (1992)

7 = Cheng and Kwan (2000)

$$
\begin{aligned}
& 2=\text { Bartik (1985) } \\
& 5=\text { Woodward (1992) } \\
& 8=\text { Wu and Strange }(2000)
\end{aligned}
$$

$\mathrm{JP}=$ Japan

$\mathrm{EU}=$ European Union

$\mathrm{B}=$ Communication transmission equipment

$\mathrm{E}=$ Insurance
$3=$ Shaver $(1998)$

$6=$ Head et al. (1995)

9 = Kittiprapas and McCann (1999)

US $=$ United States

$\mathrm{TH}=$ Thailand

\section{Industry}

A = Plastic products

$\mathrm{D}=$ All manufacturing (SIC 20-39)

$\mathrm{C}=$ Electronic components

$\mathrm{F}=$ Electronics

\section{Region}

$\mathrm{I}=$ Auto Alley

II = Non auto alley

Home country of investment

* All foreign

** Japan, West Germany, United Kingdom, Canada, Switzerland, France, Netherlands, other

Notes

NS = No significant influence on location choice

$+=$ Increased probability of choice for a particular location

- = Decreased probability of choice for a particular location 
Table 2 Counts and home countries of new foreign establishments in the Netherlands

\begin{tabular}{|c|c|c|c|c|c|}
\hline Country & 1995-1996 & $1992-1996$ & Country & 1995-1996 & 1992-1996 \\
\hline Aruba & & 1 & Liechtenstein & \multirow{9}{*}{4} & 1 \\
\hline Australia & 3 & 15 & Luxembourg & & 30 \\
\hline Austria & 4 & 11 & Malaysia & & 2 \\
\hline Belgium & 47 & 146 & Mexico & & 1 \\
\hline Brazil & & 1 & New Zealand & & 1 \\
\hline Canada & 3 & 16 & Norway & & 4 \\
\hline Denmark & 7 & 20 & Philippines & & 1 \\
\hline Fed. Rep. Germany & 54 & 239 & Portugal & & 3 \\
\hline Finland & 2 & 5 & Russian Fed. & & 1 \\
\hline France & 23 & 58 & Singapore & \multirow[t]{2}{*}{1} & 5 \\
\hline Georgië & & 1 & South Africa & & 1 \\
\hline Hong Kong & \multirow[t]{4}{*}{1} & 8 & Spain & 5 & 14 \\
\hline Hungary & & 1 & Surinam & 1 & 1 \\
\hline India & & 2 & Sweden & 7 & 28 \\
\hline Indonesia & & 1 & Switzerland & 9 & 58 \\
\hline Ireland & 4 & 26 & Taiwan & \multirow[t]{2}{*}{2} & 16 \\
\hline Israel & 4 & 17 & Turkey & & 2 \\
\hline Italy & 5 & 35 & UAE & 1 & 1 \\
\hline Japan & 17 & 81 & United Kingdom & 71 & 263 \\
\hline Republic of Korea & 3 & 9 & United States & 79 & 309 \\
\hline \multicolumn{4}{|l|}{ Total new } & 357 & 1435 \\
\hline
\end{tabular}

Source: DutchInvest database 
Table 3 Dutch establishment patterns of local and foreign firms per region, 1995

\begin{tabular}{|l|r|r|r|r|}
\hline Region & Foreign & Share of all foreign (\%) & Local & Share of all local (\%) \\
\hline Groningen & 61 & 0,9 & 21754 & 3,3 \\
Friesland & 35 & 0,5 & 27065 & 4,1 \\
Drenthe & 47 & 0,7 & 19258 & 2,9 \\
Overijssel & 171 & 2,4 & 45639 & 7,0 \\
Gelderland & 535 & 7,6 & 81435 & 12,5 \\
Utrecht & 667 & 9,4 & 45228 & 6,9 \\
Noord Holland & 2286 & 32,4 & 110589 & 16,9 \\
Zuid Holland & 1775 & 25,1 & 129060 & 19,8 \\
Zeeland & 67 & 0,9 & 18163 & 2,8 \\
Noord Brabant & 1033 & 14,6 & 99387 & 15,2 \\
Limburg & 303 & 4,3 & 45502 & 7,0 \\
Flevoland & 79 & 1,1 & 10151 & 1,6 \\
\hline
\end{tabular}

$\left(\chi_{11}^{2}=2158, \mathrm{p}<0.0001\right)$ 
Table 4 Explanatory variables

\begin{tabular}{|l|l|c|l|}
\hline Variable & Definition & $\begin{array}{c}\text { Hypothesised } \\
\text { effect }\end{array}$ & Source \\
\hline Foreign agglomeration & $\begin{array}{l}\text { Ln (number of foreign establishments) } \\
\text { Local agglomeration }\end{array}$ & + & Dn (number of local establishments) \\
Market size & Ln (Gross National Product of region) & + & CBS \\
Population density & Ln (population per km²) & + & CBS \\
Unemployment rate & Average unemployment rate per region & $?$ & CBS \\
Real estate taxes & Ln (amount of real estate taxes per & - & CBS \\
individual firm) & + & CBS \\
Infrastructure & Ln (roads per km² land area) & + & CBS \\
Cand area & Ln (Land Area in km²) & & DutchInvest \\
Sountry dummy & Dummy for establishments from particular & & \\
& countries (EU, US, Japan) & & DutchInvest \\
\hline
\end{tabular}


Table 5 Regression results

\begin{tabular}{|c|c|c|c|c|c|c|c|c|}
\hline Specification & 1 & 2 & 3 & 4 & 5 & 6 & 7 & 8 \\
\hline Years & \multicolumn{2}{|c|}{ 1995-1996 } & \multicolumn{2}{|c|}{ 1992-1996 } & \multicolumn{2}{|c|}{ 1995-1996 } & \multicolumn{2}{|c|}{ 1992-1996 } \\
\hline Regions & \multicolumn{4}{|c|}{ Randstad or not } & \multicolumn{4}{|c|}{12 Provinces } \\
\hline Constant & $\begin{array}{l}17.8^{* * *} \\
(5.84)\end{array}$ & $\begin{array}{r}-159.1^{* * *} \\
(37.81)\end{array}$ & $\begin{array}{r}14.58^{* * *} \\
(2.81)\end{array}$ & $\begin{array}{r}23.70 \\
(22.78)\end{array}$ & & & & \\
\hline Local agglomeration & $\begin{array}{l}-7.12^{* * *} \\
\quad(1.10)\end{array}$ & $\begin{array}{r}-36.2^{* * *} \\
(6.45)\end{array}$ & $\begin{array}{r}-5.94^{* * *} \\
(0.49)\end{array}$ & $\begin{array}{r}19.49^{* * *} \\
(5.88)\end{array}$ & $\begin{array}{r}0.24 \\
(0.23)\end{array}$ & $\begin{array}{r}-1.66 \\
(1.63)\end{array}$ & $\begin{array}{r}-0.04 \\
(0.11)\end{array}$ & $\begin{array}{r}-0.09 \\
(0.13)\end{array}$ \\
\hline Foreign agglomeration & $\begin{array}{l}9.01^{* * *} \\
(1.14)\end{array}$ & $\begin{array}{l}8.01^{* * *} \\
(1.30)\end{array}$ & $\begin{array}{l}7.68^{* * *} \\
(0.50)\end{array}$ & $\begin{array}{l}5.44^{* * *} \\
(1.25)\end{array}$ & $\begin{array}{l}0.76^{* * *} \\
(0.12)\end{array}$ & $\begin{array}{r}0.82^{* * *} \\
(0.32)\end{array}$ & $\begin{array}{l}0.92^{* * *} \\
(0.06)\end{array}$ & $\begin{array}{r}0.96^{* * *} \\
(0.07)\end{array}$ \\
\hline Market size & & $\begin{array}{r}27.88^{* * *} \\
(5.57)\end{array}$ & & $\begin{array}{l}-9.17^{* *} \\
(4.05)\end{array}$ & & $\begin{array}{r}0.67 \\
(0.86)\end{array}$ & & $\begin{array}{r}0.38 \\
(0.77)\end{array}$ \\
\hline Population density & & & & & & $\begin{array}{r}1.46 \\
(1.88)\end{array}$ & & $\begin{array}{r}-0.63 \\
(0.98)\end{array}$ \\
\hline Infrastructure & & $\begin{array}{r}0.74 \\
(0.63)\end{array}$ & & & & $\begin{array}{r}0.03 \\
(1.11)\end{array}$ & & $\begin{array}{r}0.29 \\
(0.77)\end{array}$ \\
\hline Property tax & & & & & & $\begin{array}{r}-2.55 \\
(2.89)\end{array}$ & & $\begin{array}{r}0.59 \\
(1.64)\end{array}$ \\
\hline Unemployment & & $\begin{array}{l}0.58^{* *} \\
(0.29)\end{array}$ & $\begin{array}{r}0.18 \\
(0.25)\end{array}$ & & & & & $\begin{array}{r}-0.04 \\
(0.04)\end{array}$ \\
\hline Land area & & & $\begin{array}{r}-14.71^{* * *} \\
(2.36)\end{array}$ & & & $\begin{array}{r}1.12 \\
(1.31)\end{array}$ & & $\begin{array}{r}-0.14 \\
(0.73)\end{array}$ \\
\hline Manufacturing & & $\begin{array}{r}0.78 \\
(0.81)\end{array}$ & & & & & & \\
\hline Holding & & $\begin{array}{c}1.44^{*} \\
(0.87)\end{array}$ & $\begin{array}{c}1.06^{* * *} \\
(0.39)\end{array}$ & & & & & \\
\hline EU & & $\begin{array}{r}0.35 \\
(0.61)\end{array}$ & & & & & & \\
\hline US & & & $\begin{array}{l}0.85^{* *} \\
(0.31)\end{array}$ & & & & & \\
\hline Japan & & & $\begin{array}{c}1.22^{*} \\
(0.62)\end{array}$ & & & & & \\
\hline
\end{tabular}


Table 5 Regression results (continued)

\begin{tabular}{|c|c|c|c|c|c|c|c|c|}
\hline Specification & 1 & 2 & 3 & 4 & 5 & 6 & 7 & 8 \\
\hline Years & \multicolumn{2}{|c|}{ 1995-1996 } & \multicolumn{2}{|c|}{$1992-1996$} & \multicolumn{2}{|c|}{ 1995-1996 } & \multicolumn{2}{|c|}{ 1992-1996 } \\
\hline Regions & \multicolumn{4}{|c|}{ Randstad or not } & \multicolumn{4}{|c|}{12 Provinces } \\
\hline Log likelihood & -103.2 & -62.6 & -437.2 & -250.7 & -688.8 & -687.5 & -2733.6 & -2731.3 \\
\hline Restricted log likelihood & -245.73 & -245.7 & -978.2 & -977.3 & & & & \\
\hline$\chi^{2}$ & $285.1^{* * *}$ & $366.2^{* * *}$ & $1080.4^{* * *}$ & $1453.2^{* * *}$ & & & & \\
\hline Number of choosers & 357 & 357 & 1434 & 1434 & 357 & 357 & 1434 & 1434 \\
\hline Number of choices & 2 & 2 & 2 & 2 & 12 & 12 & 12 & 12 \\
\hline
\end{tabular}

Notes: standard errors are shown in parentheses

${ }^{* * *}$ significant at the 1 percent level, ${ }^{* *}$ at the 5 percent level, ${ }^{*}$ at the 10 percent level.

Variables that could not be tested due to multicollinearity problems are omitted from this table. 
Table 6 Hypotheses tests

\begin{tabular}{|cl|c|c|}
\hline \multirow{2}{*}{ Hypothesis } & \multicolumn{2}{|c|}{ Confirmed? } \\
\cline { 3 - 4 } & $\begin{array}{l}\text { The presence of foreign establishments in a region positively influences } \\
\text { new foreign investment in that region }\end{array}$ & Yes & Yes \\
\hline $2 \mathrm{a}$ & $\begin{array}{l}\text { The presence of local establishments in a region positively influences } \\
\text { new foreign investment in that region } \\
\text { The presence of local establishments in a region negatively influences } \\
\text { new foreign investment in that region }\end{array}$ & No & No \\
\hline 3 & $\begin{array}{l}\text { A larger market size in a region positively influences new foreign } \\
\text { investment in that region }\end{array}$ & Yes & No \\
\hline 4 & $\begin{array}{l}\text { A higher population density in a region positively influences new } \\
\text { foreign investments in that region }\end{array}$ & No \\
\hline $5 a$ & $\begin{array}{l}\text { Higher unemployment in a region negatively influences new foreign } \\
\text { investment in that region }\end{array}$ & No \\
\hline $5 b$ & $\begin{array}{l}\text { Higher unemployment in a region positively influences new foreign } \\
\text { investment in that region }\end{array}$ & No \\
\hline 6 & $\begin{array}{l}\text { Higher real estate property taxes in a region negatively influence new } \\
\text { foreign investment in that region }\end{array}$ & No \\
\hline 7 & $\begin{array}{l}\text { Larger infrastructural provisions in a region positively influence new } \\
\text { foreign investment in that region }\end{array}$ & Yes & No \\
\hline 8 & $\begin{array}{l}\text { A larger available area in a region positively influences new foreign } \\
\text { investment in that region }\end{array}$ & No & No \\
\hline 9 & $\begin{array}{l}\text { Multinationals from countries that have a border with the Netherlands } \\
\text { are more inclined to invest in regions that are attached to their home } \\
\text { country than firms from countries that are not direct neighbours }\end{array}$ & Yes & Yes \\
\hline
\end{tabular}

For this hypothesis we find significant results opposing the suggested relationship

\# not tested due to multicollinearity problems 
Table 7 New establishments per region of firms from different home countries (1992-96)

\begin{tabular}{|l|r|r|r|r|r|r|r|}
\hline Region & All & US & UK & Germany & Belgium & Japan & All Europe \\
\hline Groningen & 11 & 2 & 2 & $\mathbf{3}$ & 1 & 2 & 7 \\
Friesland & 13 & 2 & 5 & 3 & - & 1 & 9 \\
Drenthe & 14 & 5 & 2 & $\mathbf{5}$ & 1 & - & 8 \\
Overijssel & 32 & 6 & 4 & $\mathbf{1 2}$ & 3 & 2 & 21 \\
Gelderland & 104 & 20 & 15 & $\mathbf{3 2}$ & 12 & 2 & 72 \\
Utrecht & 145 & 42 & 21 & 31 & 10 & 7 & 81 \\
Noord Holland & 416 & 104 & 86 & 41 & 16 & 41 & 225 \\
Zuid Holland & 357 & 70 & 69 & 47 & 36 & 12 & 218 \\
Zeeland & 16 & 1 & 3 & 3 & $\mathbf{5}$ & - & 12 \\
Noord Brabant & 230 & 39 & 41 & $\mathbf{3 9}$ & $\mathbf{4 7}$ & 7 & 159 \\
Limburg & 71 & 16 & 8 & $\mathbf{1 5}$ & $\mathbf{1 3}$ & 5 & 47 \\
Flevoland & 26 & 2 & 7 & 8 & 2 & 2 & 19 \\
$\chi^{2}$ 9 & & NS & NS & $44.35^{*}$ & & & NS \\
$\chi^{2}{ }_{8}$ & & & & $54.23^{*}$ & & \\
\hline
\end{tabular}

${ }^{*}$ Significant at the 0.005 percent level, Neighbouring regions are shown in bold

$\chi^{2}$ tests can be applied if every cell has at least 1 observation and no more than $20 \%$ of the cells have less than five observations. To meet these requirements, we have grouped the observations in the Northern provinces Friesland, Groningen and Drenthe. The number of degrees of freedom is reduced to nine. For Belgium, we also combined Flevoland and Noord Holland. For Japan, too many aggregations are needed to allow for $\chi^{2}$ testing. 


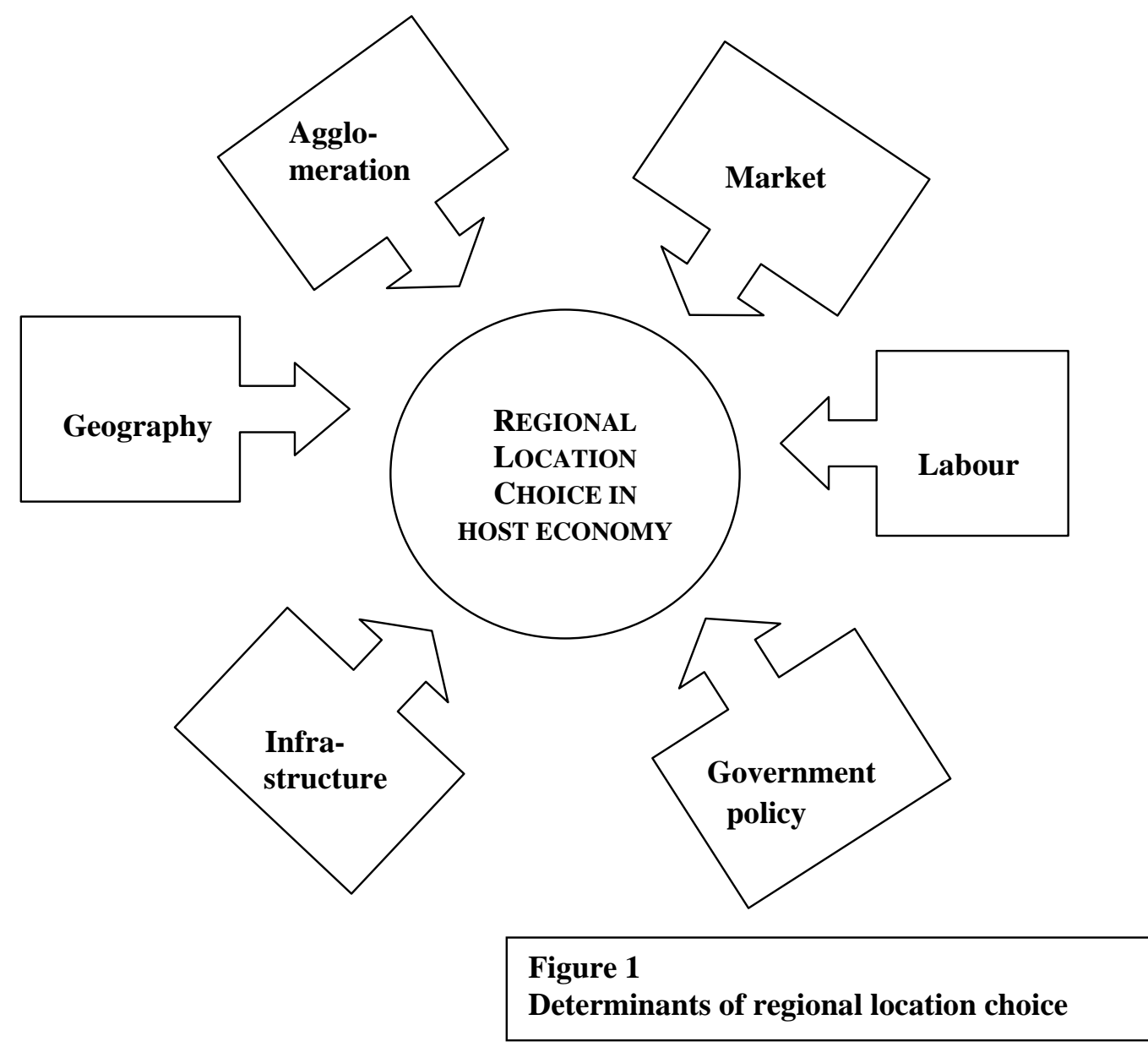




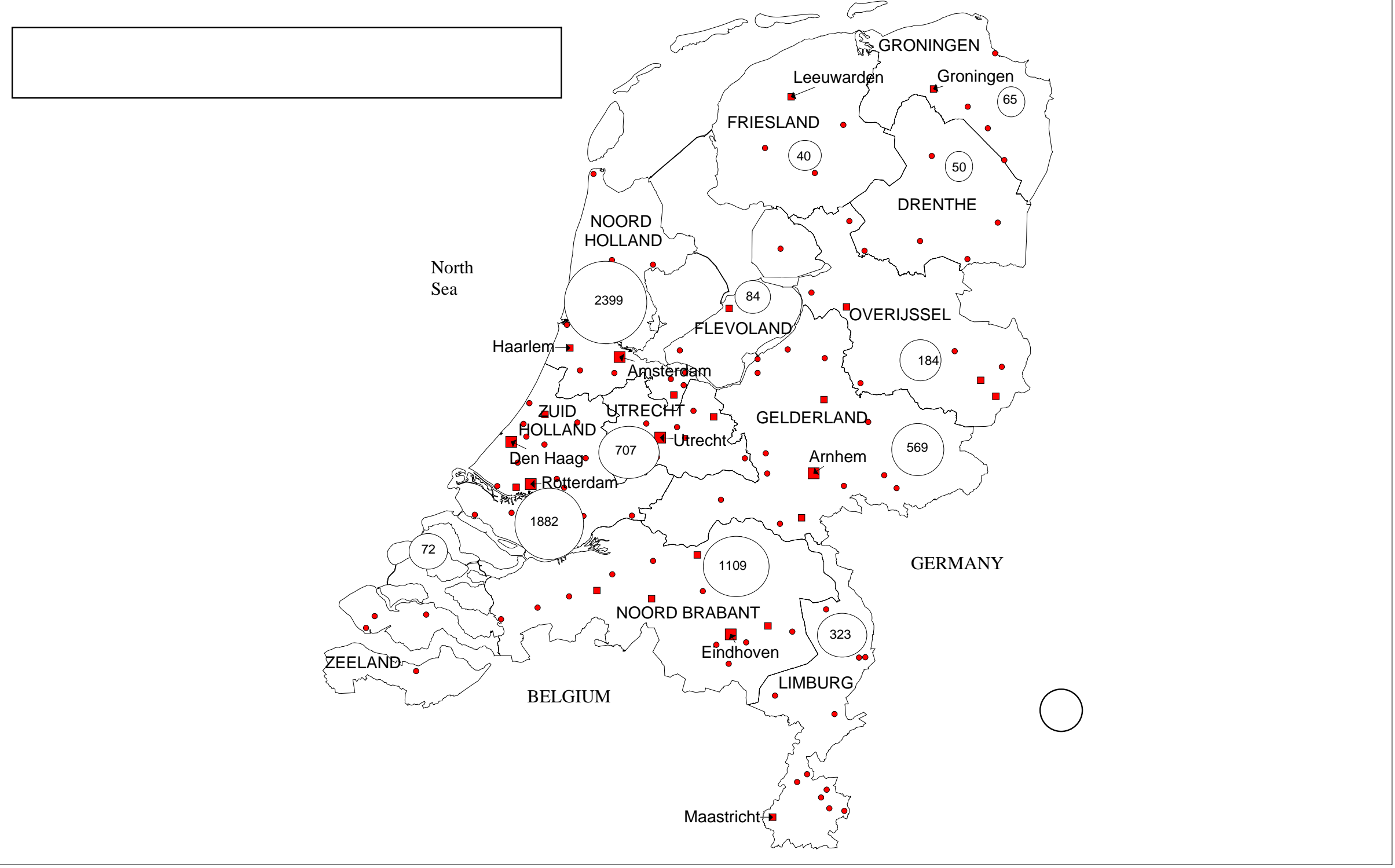




$$
\square
$$


Notes 